\title{
A glimpse into the physiological, biochemical and nutritional status of soybean plants under $\mathrm{Ni}$-stress conditions
}

\author{
André Rodrigues dos Reis ${ }^{\mathrm{a}, \mathrm{b}, *}$, Jéssica Pigatto de Queiroz Barcelos ${ }^{\mathrm{b}}$, \\ Christian Rones Wruck de Souza Osório ${ }^{\mathrm{c}}$, Elcio Ferreira Santos ${ }^{\mathrm{d}}$, \\ Lucas Aparecido Manzani Lisboa ${ }^{\mathrm{e}}$, José Mateus Kondo Santini ${ }^{\mathrm{b}}$, Maria José Dornelas dos Santos ${ }^{\mathrm{a}}$, \\ Enes Furlani Junior ${ }^{\mathrm{b}}$, Marcelo Campos ${ }^{\mathrm{b}}$, Paulo Alexandre Monteiro de Figueiredo ${ }^{\mathrm{e}}$, José Lavres ${ }^{\mathrm{d}}$, \\ Priscila Lupino Gratão ${ }^{\mathrm{f}}$
}

a São Paulo State University - UNESP, 17602-496, Tupã, SP, Brazil

b São Paulo State University - UNESP, 15385-000, Ilha Solteira, SP, Brazil

${ }^{c}$ Federal University of Mato Grosso do Sul - UFMS, 79540-000, Chapadão do Sul, MS, Brazil

' University of São Paulo - USP, 13416-000, Piracicaba, SP, Brazil

e São Paulo State University - UNESP, 17900-000, Dracena, SP, Brazil

${ }^{f}$ São Paulo State University - UNESP, 79560-000, Jaboticabal, SP, Brazil

\section{A R T I C L E I N F O}

\section{Keywords:}

Ni phytotoxicity

Oxidative stress

Gas exchange

Ni toxicity

Glycine $\max \mathrm{L}$

\begin{abstract}
A B S T R A C T
Nickel (Ni) toxicity has been reported to decrease productivity in soybean (Glycine max L.). However, soybean responses to $\mathrm{Ni}$ toxicity are not well understood. The aim of the present study was to describe Ni toxicity in soybean plants through physiological, nutritional, and ultrastructural analyses. Plants were grown in nutrient solution containing increasing $\mathrm{Ni}$ concentrations $\left(0,0.05,0.1,0.5,10\right.$, and $\left.20 \mu \mathrm{mol} \mathrm{L}^{-1}\right)$, and nutritional, anatomical, physiological and biochemical features were determined. The results revealed previously unreported detrimental effects of $\mathrm{Ni}$ toxicity on soybean plants. $\mathrm{CO}_{2}$ assimilation rates, stomatal conductance and transpiration decreased, resulting in lower biomass in soybean plants exposed to the highest Ni levels. Nitrate reductase activity increased with up to $0.05 \mu \mathrm{mol} \mathrm{L}{ }^{-1} \mathrm{Ni}$ and then decreased, indicating halted N-metabolism. Urease activity increased with increasing $\mathrm{Ni}$ availability in the nutrient solution, and peroxidase and superoxide dismutase activities were higher in plants grown at higher Ni levels. Leaf epidermal thickness (abaxial and adaxial), as well as root xylem and phloem diameter, decreased starting at $0.1 \mu \mathrm{mol} \mathrm{L}{ }^{-1} \mathrm{Ni}$. Mean Ni concentrations varied from 77.5 to $17,797.4 \mathrm{mg} \mathrm{kg}^{-1}$ in roots and 2.3 to $16,774.5 \mathrm{mg} \mathrm{kg}^{-1}$ in shoots. Soybean plants exhibited symptoms of Ni toxicity starting at $0.1 \mu \mathrm{mol} \mathrm{L}{ }^{-1} \mathrm{Ni}$, presenting mean shoot Ni concentration of $28.9 \mathrm{mg} \mathrm{kg}^{-1}$, along with leaf water loss until complete drying. The results contribute to our understanding of several physiological, biochemical and histological mechanisms of Ni toxicity in soybean, which is still poorly understood.
\end{abstract}

\section{Introduction}

Decreases in crop productivity are frequently caused by biotic and abiotic stresses (Reis et al., 2015). Heavy metal stress is an abiotic stress with important effects on agricultural systems, especially due to the global increase in soil and water pollution (Ahmad et al., 2015). Some metals are required by plants in small amounts, with the thresholds of essentiality and toxicity being very close (Santos et al., 2017). Nickel
(Ni) is an essential metal for plants because it is a structural component of the metalloenzyme urease (EC 3.5.1.5., urea amidohydrolase), which is responsible for the conversion of urea into carbon dioxide $\left(\mathrm{CO}_{2}\right)$ and ammonia $\left(\mathrm{NH}_{3}\right)$ (Dixon et al., 1975), playing an important role in nitrogen metabolism (Polacco et al., 2013; Lavres et al., 2016; Macedo et al., 2016). Ni also activates an isoform of glyoxalase I, which participates in the degradation of cytotoxic compounds (Fabiano et al., 2015). However, high Ni concentrations cause plant toxicity.

\footnotetext{
Abbreviations: $A, \mathrm{CO}_{2}$ assimilation rate; $C_{I}$, capacity of internal carbon use; ABET, epidermal thickness of the lower or abaxial face; ADET, epidermal thickness of the upper or adaxial

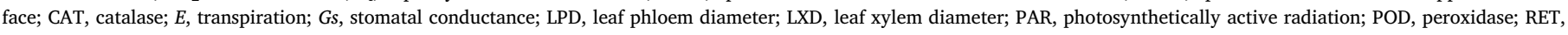
root epidermis thickness; ROS, reactive oxygen species; RPD, root phloem diameter; RXD, root xylem diameter; SOD, superoxide dismutase

* Corresponding author at: São Paulo State University - UNESP, Rua Domingos da Costa Lopes, 780 SP, Tupa 17602-496, Brazil.

E-mail addresses: andrereis@tupa.unesp.br, andrekun@gmail.com (A.R.d. Reis).
} 
Ni concentrations in the earth's crust are relatively low (approximately $20 \mathrm{mg} \mathrm{kg}^{-1}$ ), except for soils of ultramafic origin, in which $\mathrm{Ni}$ concentrations may vary between 1400 and $2000 \mathrm{mg} \mathrm{kg}^{-1}$ (KabataPendias and Pendias, 2011) and reach $7100 \mathrm{mg} \mathrm{kg}^{-1}$ in serpentine soils (Uren, 1992). However, soil Ni concentrations may increase due to contamination by metal-processing plants, oil and carbon combustion, and the use of sewage sludge and phosphate fertilizers in agriculture (Kabata-Pendias and Pendias, 2011).

Only two plant species have been reported to exhibit Ni-deficiency symptoms under field conditions: Carya illinoinensis (Wood et al., 2006) and Betula nigra (Ruter, 2005). Ni is therefore often reported to be a toxic element. The observed cases of highest Ni toxicity were mainly due to low $\mathrm{Ni}$ requirement by crops $\left(0.05\right.$ and $10 \mathrm{mg} \mathrm{kg}^{-1}$ dry mass) (Küpper and Kroneck, 2007; Küpper and Andresen, 2016). Furthermore, the difference between adequate and toxic Ni concentrations is extremely small compared with other heavy metals, whose concentrations in plants are higher than $10 \mathrm{mg} \mathrm{kg}^{-1}$ dry mass (Kabata-Pendias and Pendias, 2011).

In polluted soils, the total $\mathrm{Ni}$ concentration ranged from 200 to $26,000 \mathrm{mg} \mathrm{kg}^{-1}$ (Sreekanth et al., 2013). However, there are very few reports in the literature on the $\mathrm{Ni}$ free in contaminated soil pore waters. Nolan et al. (2009) related that the pore water free $\mathrm{Ni}^{+2}$ ranged from 5 to $250 \mu \mathrm{mol}$. Thus, the Ni accumulation and bioavailability to plants has gained great attentions recently, due to their potential health risks and food safety problems (Kabata-Pendias and Pendias, 2011).

Visual symptoms of Ni toxicity include chlorosis followed by necrosis (Gajewska et al., 2006; Seregin and Kozhevnikova, 2006; Ahmad et al., 2007), with yellowing between veins, similar to what is observed in manganese (Mn) deficiency (Hewitt, 1953). Ni toxicity also affects root and shoot growth. In more severe cases, it causes deformity of several plant parts and brown spots in leaves (Mishra and Kar, 1974). In addition, excess $\mathrm{Ni}$ leads to decreased mesophyll thickness by decreasing the intercellular spaces of the palisade and spongy parenchyma (Molas, 1997) and affects the size and diameter of main and lateral vessels, as well as the width of leaf epidermal cells (Seregin and Kozhevnikova, 2006).

Excess soil $\mathrm{Ni}$ causes an imbalance in ion uptake due to competitive inhibition, decreasing the uptake of iron (Fe), zinc $(\mathrm{Zn})$, copper $(\mathrm{Cu})$ and Mn, among others (Seregin and Ivanov, 2001; White, 2012; Nishida et al., 2015; Küpper and Andresen, 2016), and affecting aspects of plant metabolism that are dependent on these metals, e.g., the enzymes catalase and peroxidase (Granick, 1951; Kazemi et al., 2010; Sirhindi et al., 2016). In addition, Ni toxicity affects photosynthesis by inhibiting the electron transport chain and degrading photosystems I and II (Tripathy et al., 1983; Mohanty et al., 1989; Seregin and Ivanov, 2001). Ni toxicity may also disrupt chloroplast structure, block chlorophyll synthesis (Polacco et al., 2013), and inactivate Calvin cycle enzymes (Sheoran et al., 1990; Seregin and Ivanov, 2001).

$\mathrm{Ni}$ excess in plants leads to stomatal closure, limiting $\mathrm{CO}_{2}$ uptake (Sheoran et al., 1990; Bishnoi et al., 1993), and increased formation of reactive oxygen species, which damage several biomolecules (Ahmad, 2013; Ahmad et al., 2015; Sirhindi et al., 2016). Plants tend to decrease Ni stress by increasing the activity of antioxidant enzymes, such as superoxide dismutase, catalase, and peroxidase (Schickler and Caspi, 1999; Pandolfini et al., 1992; Seregin and Ivanov, 2001; Kazemi et al., 2010; Sirhindi et al., 2016). Although physiological disorders caused by $\mathrm{Ni}$ toxicity have been reported for different plant species, the physiological responses of soybean plants exposed to excess $\mathrm{Ni}$ are not well described. The hypothesis of this work is that soybean plants under $\mathrm{Ni}$ stress has the nutritional, anatomical and physiological characteristics impaired, reducing its growth and development. Thus, the aim of the present study was to describe Ni toxicity in soybean plants through physiological, nutritional and ultrastructural analyses.

\section{Materials and methods}

\subsection{Growth conditions and experimental design}

Soybean seeds of the variety BMX Potência RR were germinated in plastic pots with vermiculite. Uniform young seedlings at 21 days after sowing were washed with deionized water and transplanted into 6-L polyethylene pots containing nutrient solution with $25 \%$ ionic strength and lacking $\mathrm{Ni}$ (Hoagland and Arnon, 1950). After 5 days of plant adaptation to these nutrient solutions, $\mathrm{Ni}$ treatments of 0 (control), $0.05,0.1,0.5,10$, and $20 \mu \mathrm{mol} \mathrm{L}{ }^{-1}$, with $100 \%$ ionic strength in the nutrient solution, were applied. Constant aeration was maintained in all pots.

The experimental design was completely randomized, with four replicates. $\mathrm{Ni}$ was provided in the form of $\mathrm{NiCl}_{2}$. The complete nutrient solution contained $12.0 \mathrm{mmol} \mathrm{L}^{-1} \mathrm{~N}_{-\mathrm{NO}_{3}}{ }^{-}, 4.0 \mathrm{mmol} \mathrm{L}^{-1} 0 \mathrm{~N}_{-} \mathrm{NH}_{4}{ }^{+}$, $2.0 \mathrm{mmol} \mathrm{L}^{-1}$ phosphorus (P), $6.0 \mathrm{mmol} \mathrm{L}^{-1}$ of potassium (K), $4.0 \mathrm{mmol} \mathrm{L}^{-1}$ calcium (Ca), $2.0 \mathrm{mmol} \mathrm{L}^{-1}$ magnesium $(\mathrm{Mg})$, $2.0 \mathrm{mmol} \mathrm{L}^{-1}$ sulfur (S), $25.0 \mu \mathrm{mol} \mathrm{L}^{-1}$ boron (B), $0.5 \mu \mathrm{mol} \mathrm{L}^{-1} \mathrm{Cu}$, $54.0 \mu \mathrm{mol} \mathrm{L}^{-1} \mathrm{Fe}, \quad 2.0 \mu \mathrm{mol} \mathrm{L}^{-1} \mathrm{Mn}, \quad 2.0 \mu \mathrm{mol} \mathrm{L}^{-1} \mathrm{Zn}$, and $0.5 \mu \mathrm{mol} \mathrm{L}^{-1}$ molybdenum (Mo). The initial pH (approximately $5.0 \pm 0.5$ ) was monitored daily in each experimental unit to ensure the availability of $\mathrm{Ni}$; this $\mathrm{pH}$ range was fixed throughout the experiment. Estimates of the Ni species were obtained using Visual Minteq version 3.1 software (Gustafsson, 2011), and in all of treatments, approximately $90 \%$ of the $\mathrm{Ni}$ was available $\left(\mathrm{Ni}^{2+}\right)$ for ready uptake.

Gas exchange, urease activity, and nitrate reductase activity tests, as well as extraction of antioxidant enzymes and proteins, were performed $48 \mathrm{~h}$ after plant exposure to $\mathrm{Ni}$ between 8:00 and 12:00 AM, using the first fully developed trifoliate. Antioxidant enzymes and proteins were also extracted from roots. At the end of the experiment, when the symptoms of Ni toxicity had worsened (7 days of exposure to $\mathrm{Ni}$ ), the first fully developed trifoliate was collected for leaf diagnosis (Lavres Junior et al., 2009, 2010) and to characterize the symptoms of $\mathrm{Ni}$ toxicity (leaf morphology and scanning electron microscopy).

\subsection{Gas exchange parameters}

Gas exchange was evaluated via non-destructive analyses using a portable gas exchange device (Infra-Red Gas Analyzer - IRGA, brand ADC BioScientific Ltd, model LC-Pro). The following parameters were determined: $\mathrm{CO}_{2}$ assimilation rate expressed by area $\left(\mathrm{A}-\mu \mathrm{mol} \mathrm{CO}_{2}\right.$

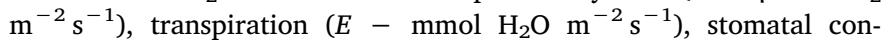
ductance $\left(G_{S}-\mathrm{mol} \mathrm{H}_{2} \mathrm{O} \mathrm{m} \mathrm{m}^{-2} \mathrm{~s}^{-1}\right)$, and internal $\mathrm{CO}_{2}$ concentration in the substomatal chamber $\left(C_{I}-\mu \mathrm{mol} \mathrm{mol}{ }^{-1}\right)$. The initial conditions imposed for the measurements were $1000 \mu \mathrm{mol} \mathrm{m}^{-2} \mathrm{~s}^{-1}$ of photosynthetically active radiation (PAR), provided by LED lamps, $380 \mathrm{ppm}$ of $\mathrm{CO}_{2}$, and a chamber temperature of $28^{\circ} \mathrm{C}$, according to Santos et al. (2017).

\subsection{Activity of urease (EC 3.5.1.5)}

Urease activity was measured according to the whole-tissue method of Hogan et al. (1983) and with ammonium determination as suggested by McCullough (1967). One hundred milligrams of fresh tissue cut in discs was transferred to assay tubes containing $8 \mathrm{~mL}$ of $50 \mathrm{mM}$ phosphate buffer ( $\mathrm{pH} 7.4$ ), $0.2 \mathrm{M}$ urea, and $0.6 \mathrm{M} n$-propanol for a period of $3 \mathrm{~h}$. After incubation, a $0.5-\mathrm{mL}$ aliquot of supernatant was added to $2.5 \mathrm{~mL}$ of Reagent I ( $0.1 \mathrm{M}$ phenol and $170 \mu \mathrm{M}$ sodium nitroprusside). Afterward, $2.5 \mathrm{~mL}$ of Reagent II $(0.125 \mathrm{M} \quad \mathrm{NaOH}+0.15 \mathrm{M}$ $\left.\mathrm{Na}_{2} \mathrm{HPO}_{4} \cdot 12 \mathrm{H}_{2} \mathrm{O}+\mathrm{NaOCl}\left(3 \% \mathrm{Cl}_{2}\right)\right)$ was added for the determination of ammonium. This reaction was performed in capped assay tubes under continuous shaking in a water bath at $37^{\circ} \mathrm{C}$ for $35 \mathrm{~min}$. Ammonium was measured in a spectrophotometer at $625 \mathrm{~nm}$ using a $\mathrm{NH}_{4} \mathrm{Cl}$ standard calibration curve, and urease activity was expressed as $\mu \mathrm{mol}$ $\mathrm{N}-\mathrm{NH}_{4}{ }^{+} \mathrm{h}^{-1} \mathrm{~g}^{-1} \mathrm{FW}$ (fresh weight). 


\subsection{Activity of nitrate reductase (EC 1.7.1.1)}

In vivo nitrate reductase activity was determined according to Reis et al. (2009) with slight modifications. Leaf samples were collected at 8:30 AM, stored in plastic bags, and transported to the laboratory on ice. Afterward, $200 \mathrm{mg}$ of fresh tissue cut in discs was transferred to assay tubes containing $5 \mathrm{~mL}$ of phosphate buffer solution, $\mathrm{pH} 7.5$ (100 $\mathrm{mM}$ potassium phosphate buffer $+100 \mathrm{mM} \mathrm{KNO}{ }_{3}$ ). Thereafter, the assay tubes (wrapped in aluminum foil to protect them from light) were incubated in a $30{ }^{\circ} \mathrm{C}$ water bath for $60 \mathrm{~min}$. The reaction was performed with $100 \mu \mathrm{L}$ of supernatant $+1.9 \mathrm{~mL}$ of distilled water $+0.5 \mathrm{~mL}$ of $1 \%$ sulfanilamide in $2 \mathrm{M} \mathrm{HCl}$, followed by $0.5 \mathrm{~mL}$ of $0.02 \%$ naphtylenediamine solution. The nitrite $\left(\mathrm{NO}_{2}{ }^{-}\right)$produced was measured in a spectrophotometer at $540 \mathrm{~nm}$ using a nitrite standard calibration curve. Enzyme activity was directly related to the amount of $\mathrm{NO}_{2}{ }^{-}$, and the results were expressed in $\mu \mathrm{mol} \mathrm{NO}{ }_{2}^{-} \mathrm{g}^{-1} \mathrm{~h}^{-1} \mathrm{FW}$.

\subsection{Extraction of antioxidant enzymes and proteins}

Plant material was macerated in a mortar containing liquid nitrogen. Protein extracts were obtained from $1.5 \mathrm{~g}$ of fresh plant material, together with the addition of PVPP (polyvinylpolypyrrolidone) corresponding to $20 \%(\mathrm{w}: \mathrm{v})$. Protein extraction proceeded using a potassium phosphate buffer solution at $100 \mathrm{mmol} \mathrm{L}^{-1}$ (pH 7.5), EDTA (ethylenediaminetetraacetic acid) at $1 \mathrm{mmol} \mathrm{L}^{-1}$, and DDT (dithiothreitol) at $1 \mathrm{mmol} \mathrm{L}^{-1}$. The homogenized extracts were centrifuged at $10,000 \mathrm{rpm}$ for $30 \mathrm{~min}$ at $4{ }^{\circ} \mathrm{C}$. The supernatant was collected in Eppendorf tubes, frozen in liquid nitrogen, and stored at $-80^{\circ} \mathrm{C}$. The soluble protein concentration was determined by the method of Bradford (1976) using BSA (bovine serum albumin) as a standard. Aliquots of $100 \mu \mathrm{L}$ of extract were mixed with $5 \mathrm{~mL}$ of Bradford reagent with four replicates. Readings were performed on a spectrophotometer at $595 \mathrm{~nm}$. The results were used to calculate the antioxidant enzyme concentrations.

\subsection{Peroxidase activity (POD, EC. 1.11.1.7)}

The method of Allain et al. (1974) was used to determine the POD activity present in the leaf tissues of soybean. From tissue extracts obtained by the enzymatic extraction process described above, $0.5-\mathrm{mL}$ aliquots were removed and added to $0.5 \mathrm{~mL}$ of $0.2 \mathrm{M}$ potassium phosphate buffer ( $\mathrm{pH}$ 6.7), $0.5 \mathrm{~mL}$ of $\mathrm{H}_{2} \mathrm{O}_{2}$ (hydrogen peroxide), and $0.5 \mathrm{~mL}$ of aminoantipyrine. The tubes were placed in a water bath at $30{ }^{\circ} \mathrm{C}$ for $5 \mathrm{~min}$. After incubation, $2 \mathrm{~mL}$ of ethanol was added to stop the reaction, and after being cooled to room temperature, the samples were vortexed and read on a spectrophotometer $(\lambda=505 \mathrm{~nm})$. As a control, the enzyme extract was replaced with $0.2 \mathrm{M}$ potassium phosphate buffer $(\mathrm{pH}$ 6.7). The total enzyme activity was expressed in $\mu$ mol de $\mathrm{H}_{2} \mathrm{O}_{2}$ $\min ^{-1} \mathrm{mg}^{-1}$ of protein.

\subsection{Superoxide dismutase activity (SOD, EC 1.15.1.1)}

SOD activity was determined according to Giannopolitis and Ries (1977). The reaction was conducted in a reaction chamber (box) under illumination with a $15 \mathrm{~W}$ fluorescent lightbulb at $25^{\circ} \mathrm{C}$. An aliquot $(50 \mu \mathrm{L})$ of the sample was added to a 5 -mL mixture of sodium phosphate buffer $\left(50 \mathrm{mmol} \mathrm{L}^{-1}\right)$, $\mathrm{pH} 7.8$, methionine $\left(13 \mathrm{mmol} \mathrm{L}^{-1}\right)$, NBT $\left(75 \mathrm{mmol} \mathrm{L}^{-1}\right)$, EDTA $\left(0.1 \mathrm{mmol} \mathrm{L}^{-1}\right)$, and riboflavin $\left(2 \mu \mathrm{mol} \mathrm{L}^{-1}\right)$. The tubes were placed inside the box, closed to any external light, and maintained under box lighting for $15 \mathrm{~min}$ for the formation of the blue formazan compound produced by the photoreaction of NBT. Other tubes containing the same mixture were covered with aluminum foil to prevent light exposure; these test tubes served as the control for each sample. After $15 \mathrm{~min}$, the material was homogenized by vortexing. Readings were taken on a spectrophotometer at $560 \mathrm{~nm}$, and the results were expressed as U SOD $\mathrm{mg}^{-1}$ protein.
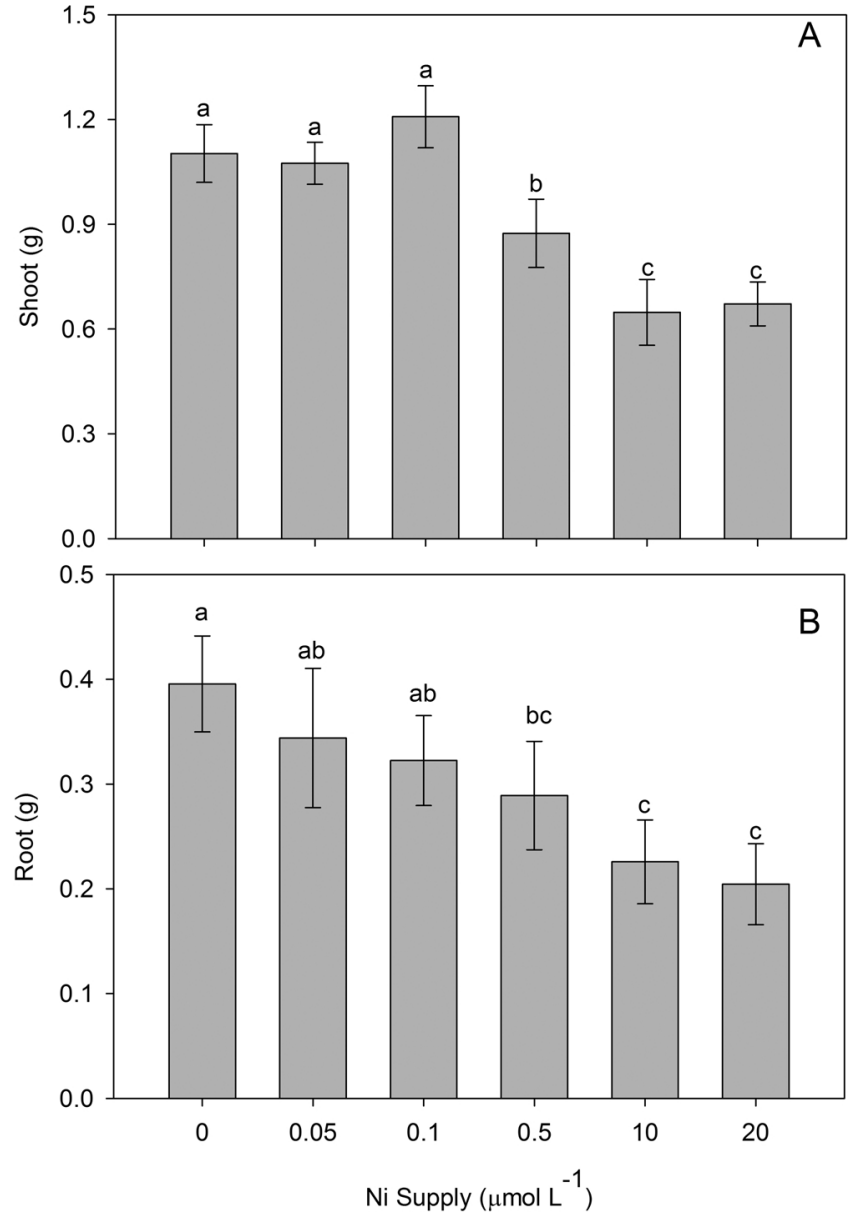

Fig. 1. Dry mass of shoots (A) and roots (B) of soybean plants grown at different $\mathrm{Ni}$ concentrations in the nutrient solution. Letters indicate significant differences at $P \leq 0.05$. Error bars indicate the standard error $(n=4)$.

\subsection{Catalase activity (CAT, EC 1.11.1.6)}

CAT activity was determined by monitoring the degradation of $\mathrm{H}_{2} \mathrm{O}_{2}$ at $240 \mathrm{~nm}$ according to the method of Azevedo et al. (1998). First, $1 \mathrm{~mL}$ of $100 \mathrm{mM}$ potassium phosphate buffer, $\mathrm{pH} 7.5$, and $2 \mu \mathrm{L}$ of $\mathrm{H}_{2} \mathrm{O}_{2}$ $30 \%$ were added to each tube, followed by $150 \mu \mathrm{L}$ of protein extract. Immediately after the addition of the protein extract, the tubes were quickly mixed by vortexing. Enzyme activity was determined by the decomposition of $\mathrm{H}_{2} \mathrm{O}_{2}$ during a 2-min interval in a spectrophotometer at a wavelength of $240 \mathrm{~nm}$ at $25^{\circ} \mathrm{C}$. The results were expressed in $\mu \mathrm{M}$ $\min ^{-1} \mathrm{mg}^{-1}$ protein.

\subsection{Dry mass production of the plants}

At harvest (phonological stage V4), the plants were separated into shoots (leaves + stem) and roots. The material was identified, packaged in paper bags, and dried in an oven at $\pm 65^{\circ} \mathrm{C}$ for 2 days, followed by the measurement of dry mass.

\subsection{Chemical analysis of plant tissue}

The concentrations of $\mathrm{P}, \mathrm{K}, \mathrm{Ca}, \mathrm{Mg}, \mathrm{S}, \mathrm{B}, \mathrm{Cu}, \mathrm{Fe}, \mathrm{Mn}$, and $\mathrm{Zn}$ were determined in the shoots and roots. Nitric-perchloric digestion was performed (Miller, 1998), and the identity and amount of nutrients were determined using radial visualization on an inductively coupled plasma optical emission spectrometer (ICP-OES) equipped with a nebulization chamber. The following emission lines were used: $\mathrm{P}_{\mathrm{I}}$

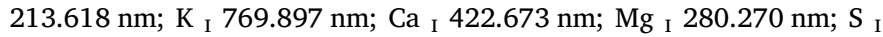



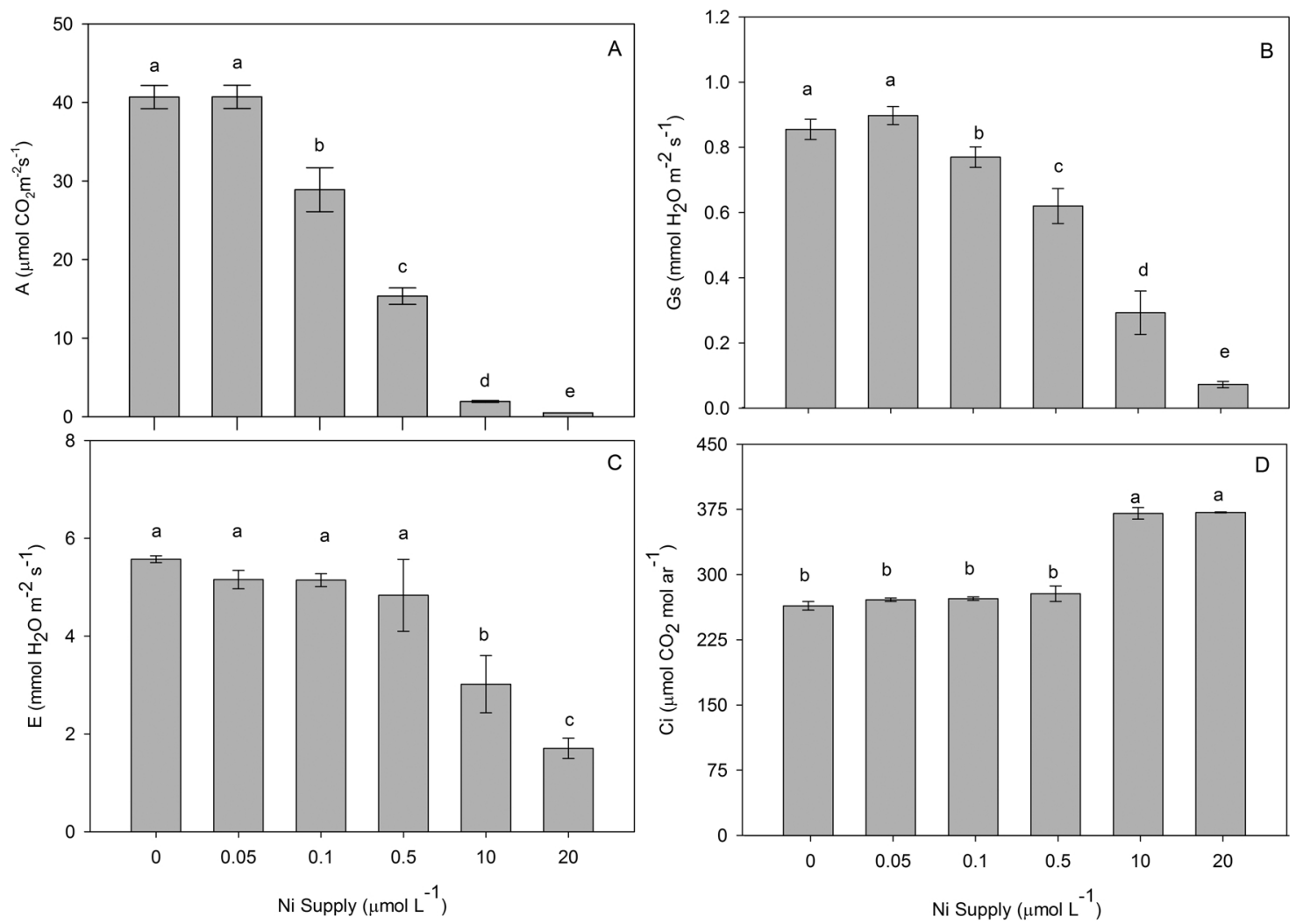

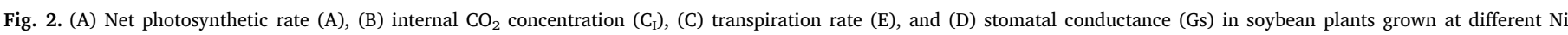
concentrations in the nutrient solution. Letters indicate significant differences at $\mathrm{P} \leq 0.05$. Error bars indicate the standard error $(\mathrm{n}=4)$.

$181.972 \mathrm{~nm} ; \mathrm{B}_{\text {I }} 249.773 \mathrm{~nm} ; \mathrm{Cu}_{\mathrm{I}} 324.754 \mathrm{~nm} ; \mathrm{Fe}_{\text {II }} 259.940 \mathrm{~nm} ; \mathrm{Mn}_{\text {II }}$ $259.373 \mathrm{~nm} ; \mathrm{Zn}_{\text {II }} 231.865 \mathrm{~nm}$; and $\mathrm{Ni}_{\text {II }} 231.604$.

\subsection{Leaf and root morphology}

After 7 days of exposure to $\mathrm{Ni}$ (phonological stage V1), plants were collected for symptomatology and histological analysis. Leaf and root fragments were collected and fixed in F.A.A. 70 solution (37\% formaldehyde and acetic acid and $70 \%$ ethanol at a ratio of 1.0:1.0:18.0-V/V) and stored until analysis according to the method described by Santos et al. (2017).

All plant tissue fragments received the relevant procedures for dehydration, diafanization, inclusion, and fixation. With the aid of a Leica microtome table containing a steel blade, 8 - to $14-\mu \mathrm{m}$ sections were cut from each embedded fragment. For the histological slides, the first cross-sections that showed the best preserved material were selected, i.e., without damage or injury caused by cutting the plant tissue. All of the chosen sections were fixed with Mayer adhesive, stained with 1\% safranin, and mounted on slides and cover slips with Entellan adhesive. All of the slides were observed on an Olympus optical microscope with a coupled camera to measure anatomical parameters using the CellSens Standard image analysis program, calibrated with a microscopic rule at the same zoom level of the photographs.

In the midrib region of the leaves in the cross-sections, the following morphoanatomic characteristics were observed: epidermal thickness of the lower or abaxial face (ABET), epidermal thickness of the upper or adaxial face (ADET), leaf phloem diameter (LPD), and leaf xylem diameter (LXD). The morphoanatomic root characteristics obtained were root epidermis thickness (RET), root phloem diameter (RPD), and root xylem diameter (RXD) (Carlquist, 1975). For each characteristic, 10 measurements were performed per slide. Plots show the mean values obtained for each characteristic.

\subsection{Scanning electron microscopy}

Leaf and root plant material was fixed in modified Karnovsky fixative $(2.5 \%$ glutaraldehyde and $2.5 \%$ formaldehyde in $0.05 \mathrm{M}$ sodium cacodylate buffer, $\mathrm{pH}$ 7.2), post-fixed with osmium tetroxide $\left(\mathrm{OsO}_{4}\right)$, and dehydrated in increasing solutions of acetone (30,50, 70, 90, and $100 \%)$. Subsequently, the specimens were dried to their critical point with liquid $\mathrm{CO}_{2}$ (Balzers CPD 030), sputter-coated (MED 010 Balzers) with a thin layer of gold, and examined on a scanning electron microscope (EVO-LS15-ZEIS), as described in our previous study (Santos et al., 2017).

\subsection{Statistical analysis}

In all of the datasets considered, the normality of the data was analyzed using the Anderson-Darling test, and homoscedasticity was analyzed with the variance equation test (or Levene's test). The results were subjected to statistical analysis using SAS statistical software System for Windows 9.2. The means were compared using the Tukey test $(\mathrm{p}<0.05)$.

\section{Results}

\subsection{Dry mass production}

Shoot dry mass production decreased with Ni levels equal to or higher than $0.1 \mu \mathrm{mol} \mathrm{L}^{-1}$ (Fig. 1A). The highest Ni levels (10 and $20 \mu \mathrm{mol} \mathrm{L}^{-1}$ ) resulted in decreases of up to $41 \%$ relative to the mean dry mass production for plants grown with $0,0.05$, or $0.1 \mu \mathrm{mol} \mathrm{L}^{-1} \mathrm{Ni}$ in the nutrient solution. It should be noted that in the present study, the nutrient solution was kept at $\mathrm{pH} 5$ in order to intensify Ni toxicity. Root dry mass was more sensitive to $\mathrm{Ni}$ in the nutrient solution (Fig. 1B), decreasing with $\mathrm{Ni}$ levels higher than $0.05 \mu \mathrm{mol} \mathrm{L}^{-1}$. However, the 


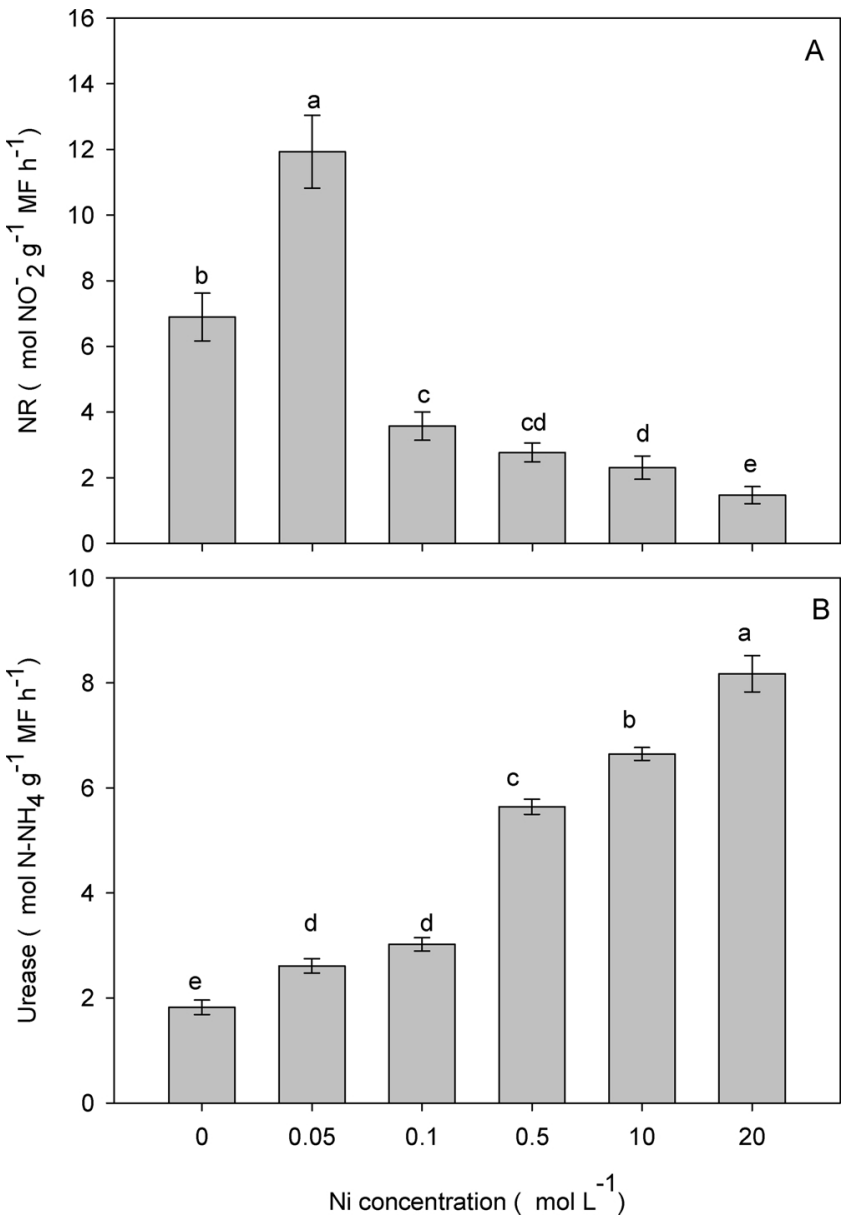

Fig. 3. Activity of nitrate reductase (A) and urease (B) in leaves of soybean plants grown at different $\mathrm{Ni}$ concentrations in the nutrient solution. Letters indicate statistically significant differences at $P \leq 0.05$. Error bars indicate the standard error $(n=4)$.

highest Ni levels (10 and $20 \mu \mathrm{mol} \mathrm{L}^{-1}$ ) resulted in a decrease of approximately $37 \%$ relative to the control $\left(0 \mu \mathrm{mol} \mathrm{L}^{-1}\right)$, similar to that observed for the shoot (Fig. 1A).

\subsection{Gas exchange and nitrogen-assimilating enzymes}

$A, G s$, and $E$ decreased with increasing Ni concentrations in the nutrient solution (Fig. 2A, B and C). The highest Ni concentration $\left(20 \mu \mathrm{mol} \mathrm{L}^{-1}\right)$ decreased $A$ by $98 \%$, Gs by $92 \%$, and $E$ by $70 \%$ compared with plants grown at the lowest Ni concentration. It should be highlighted that decreases in $E$ were only observed with 10 and $20 \mu \mathrm{mol} \mathrm{L}^{-1} \mathrm{Ni}$ (Fig. 2C). In contrast to other gas exchange parameters, $C_{I}$ was higher at the highest $\mathrm{Ni}$ concentrations (10 to $20 \mu \mathrm{mol} \mathrm{L}^{-1}$ ) (Fig. 2D).

$\mathrm{N}$ metabolism enzymes responded differently to $\mathrm{Ni}$ concentrations in the nutrient solution. NR activity increased $84 \%$ with $0.05 \mu \mathrm{mol} \mathrm{L}^{-1}$ $\mathrm{Ni}$ relative to the control (Fig. 3A) but showed a pronounced decreased at the highest $\mathrm{Ni}$ concentrations. On the other hand, urease activity increased up to $300 \%$ with $20 \mu \mathrm{mol} \mathrm{L}^{-1} \mathrm{Ni}$ relative to the control (Fig. 3B).

\subsection{Antioxidant enzymes}

Shoot soluble protein concentrations decreased $47 \%$ with increasing Ni levels (Fig. 4A). However, root soluble protein increased $27 \%$ with $0.05 \mu \mathrm{mol} \mathrm{L}{ }^{-1} \mathrm{Ni}$ and decreased $87 \%$ at the highest $\mathrm{Ni}$ concentrations in the nutrient solution ( 10 to $20 \mu \mathrm{mol} \mathrm{L}^{-1}$ ) compared with the control.

Oxidative stress enzymes exhibited different behaviors. POD activity in shoots was highest at the highest $\mathrm{Ni}$ level $\left(20 \mu \mathrm{mol} \mathrm{L}^{-1}\right)$, presenting a five-fold increase (Fig. 4C). However, POD activity in roots increased up to 10 -fold with $10 \mu \mathrm{mol} \mathrm{L}^{-1} \mathrm{Ni}$ (Fig. 4D).

SOD activity in shoots did not change significantly with 0.05 and $0.1 \mu \mathrm{mol} \mathrm{L}^{-1} \mathrm{Ni}$ but was highest at the highest $\mathrm{Ni}$ concentration $\left(20 \mu \mathrm{mol} \mathrm{L}^{-1}\right)$ (Fig. 4E). No significant differences in SOD activity in roots were observed between $0.05 \mu \mathrm{mol} \mathrm{L}^{-1} \mathrm{Ni}$ and the control (Fig. 4F). SOD activity was highest for plants grown at the highest $\mathrm{Ni}$ levels $\left(10-20 \mu \mathrm{mol} \mathrm{L}^{-1}\right)$, presenting a 10 -fold increase relative to the control.

CAT activity behaved similarly in roots and shoots, increasing with up to $0.5 \mu \mathrm{mol} \mathrm{L}^{-1} \mathrm{Ni}$ and then decreasing at increasing $\mathrm{Ni}$ levels (Fig. 4G and $\mathrm{H}$ ).

\subsection{Leaf and root morphology}

Ni supplies higher than $0.05 \mu \mathrm{mol} \mathrm{L}^{-1}$ had a negative effect on the epidermal thickness of the leaf abaxial and adaxial surfaces (Figs. 5 A, B and 6), as well as on root phloem and xylem diameter (Figs. 5C, D and 7 ). This decrease in vascular tissues reached approximately $40 \%$ in roots and was more pronounced in the leaf adaxial and abaxial epidermis, reaching $50 \%$.

The increase in Ni supply led to changes in leaf color due to $\mathrm{Ni}$ accumulation in leaves (Fig. 8). Increased leaf $\mathrm{Ni}$ concentrations promoted chlorosis and the predominance of brown color. It should be noted that leaf toxicity symptoms were more evident with $20 \mu \mathrm{mol} \mathrm{L}{ }^{-1}$ Ni. Electron microscopy images of the abaxial (Fig. 9) and adaxial (Fig. 10) epidermis revealed detrimental effects proportional to the increase in leaf color. Increased $\mathrm{Ni}$ availability in the nutrient solution therefore increased cellular atrophy in the leaf epidermis. In addition, the leaf central vein region presented tissue disorganization with increasing $\mathrm{Ni}$ doses in the nutrient solution. Plants subjected to excess $\mathrm{Ni}$ displayed decreased root xylem and phloem diameters (Fig. 5C and D), indicating a detrimental effect of Ni toxicity (Fig. 7). Changes in leaf and root morphology due to toxicity caused by excess Ni were more pronounced in plants grown in $20 \mu \mathrm{mol} \mathrm{L}^{-1}$.

\subsection{Nutrient concentrations}

No significant differences in shoot nutrient concentrations were observed between different Ni levels. However, significant differences were observed in root macro- and micronutrient concentrations (Fig. 11). The first effect of interionic interactions (competitive and non-competitive inhibition) on nutrient uptake is to change root nutrient uptake rates. Therefore, because of the exposure time in the present study $(72 \mathrm{~h})$, only effects on root nutrient uptake were observed. Phosphorus, $\mathrm{Ca}$, and $\mathrm{Mn}$ concentrations decreased with increasing Ni concentrations in the nutrient solution (Fig. 11A, C and G). Changes in $\mathrm{K}$ concentrations were only observed at 10 and $20 \mu \mathrm{mol} \mathrm{L}-1$ $\mathrm{Ni}$ (Fig. 11B), for which lower $\mathrm{K}$ concentrations were observed compared with the remaining treatments.

Different trends were observed for micronutrients. Boron and $\mathrm{Zn}$ concentrations increased with increasing $\mathrm{Ni}$ supply up to 1 and $0.5 \mu \mathrm{mol} \mathrm{L}^{-1}$, respectively, and then decreased (Fig. 11D and $\mathrm{H}$ ). Copper and $\mathrm{Fe}$ concentrations were higher for plants grown in 10 or $20 \mu \mathrm{mol} \mathrm{L}^{-1} \mathrm{Ni}$ (Fig. 11E and F).

Mean Ni concentrations varied between 77.5 and $17,797.4 \mathrm{mg} \mathrm{kg}^{-1}$ in roots and between 2.3 and $16,774.5 \mathrm{mg} \mathrm{kg}^{-1}$ in shoots (Fig. 12). Soybean plants exhibited symptoms of Ni toxicity at $\mathrm{Ni}$ levels equal to or higher than $0.1 \mu \mathrm{mol} \mathrm{L}{ }^{-1}$, with a mean shoot Ni concentration of $28.9 \mathrm{mg} \mathrm{kg}^{-1}$, and leaf water loss until complete drying (Fig. 8). 

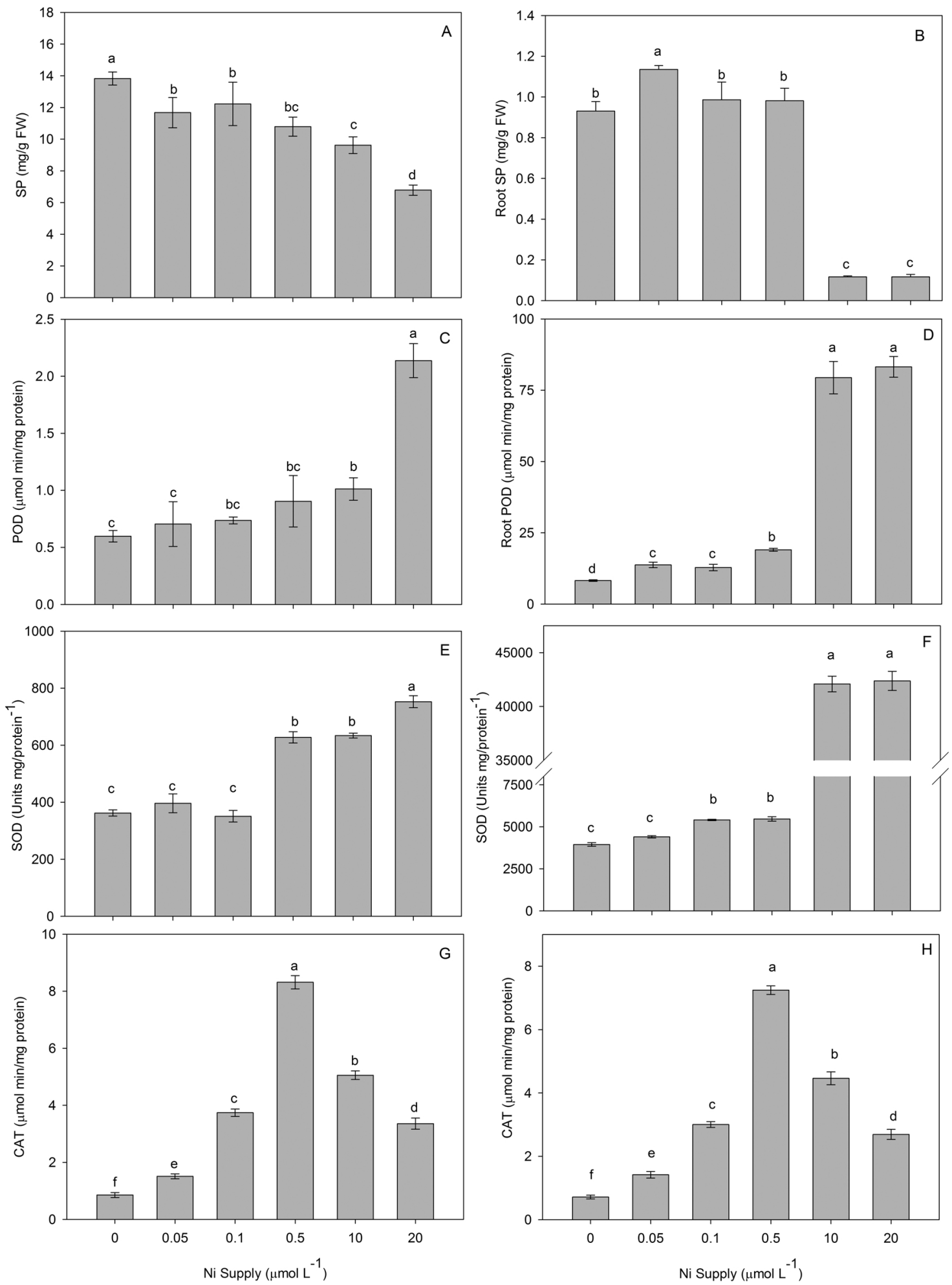

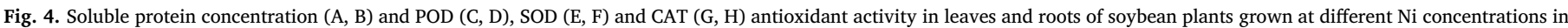
the nutrient solution. Letters indicate significant differences at $P \leq 0.05$. Error bars indicate the standard error $(n=4)$.

\section{Discussion}

\subsection{Dry mass production, gas exchange and nitrogen-assimilating enzymes}

Plant dry mass was affected by the Ni supply. Plant growth was not compromised with $0.05 \mu \mathrm{mol} \mathrm{L}{ }^{-1} \mathrm{Ni}$ in the nutrient solution, but higher $\mathrm{Ni}$ supplies led to excess $\mathrm{Ni}$ uptake, resulting in decreased photosynthetic activity (Fig. 2), visible toxicity symptoms, and subsequent tissue necrosis (Fig. 8). These effects were previously observed in corn (Drazkiewicz and Baszynki, 2010), Populus nigra (Velikova et al., 2011) and cauliflower (Shukla et al., 2015). It is noteworthy that the toxicity symptoms were found in plants grown at $\mathrm{Ni}$ supply in grown solution similar to the pore water free $\mathrm{Ni}$ in polluted soils (Nolan et al., 2009).

$\mathrm{NR}$ activity increased at $0.05 \mu \mathrm{mol} \mathrm{L}{ }^{-1} \mathrm{Ni}$ (Fig. 3A), whereas urease activity increased with increasing $\mathrm{Ni}$ concentrations in the nutrient solution (Fig. 3B). Soybean plants with adequate Ni concentrations 

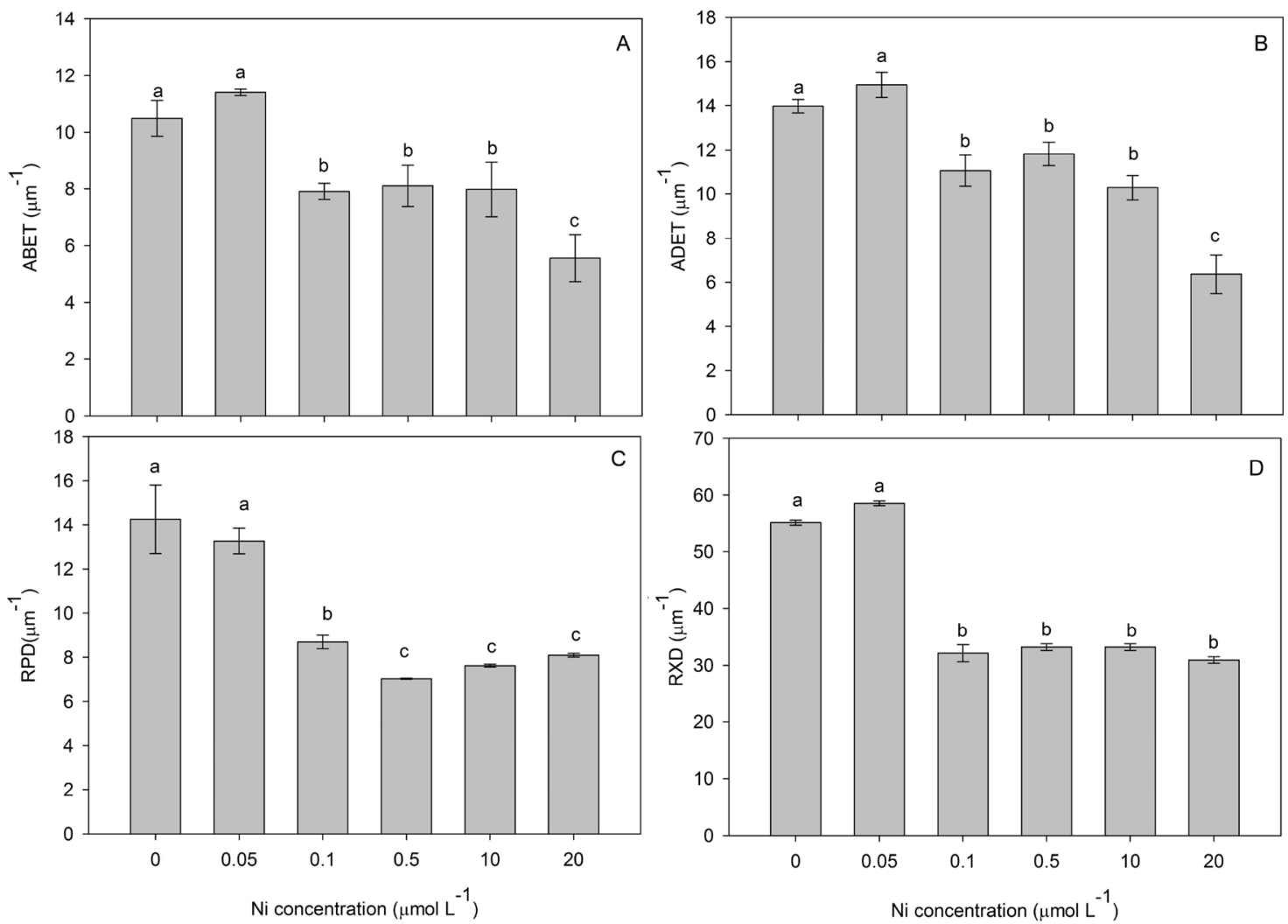

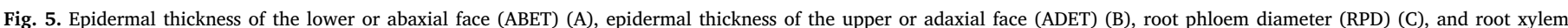

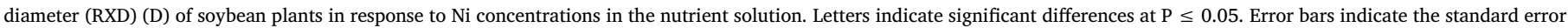
$(n=4)$.

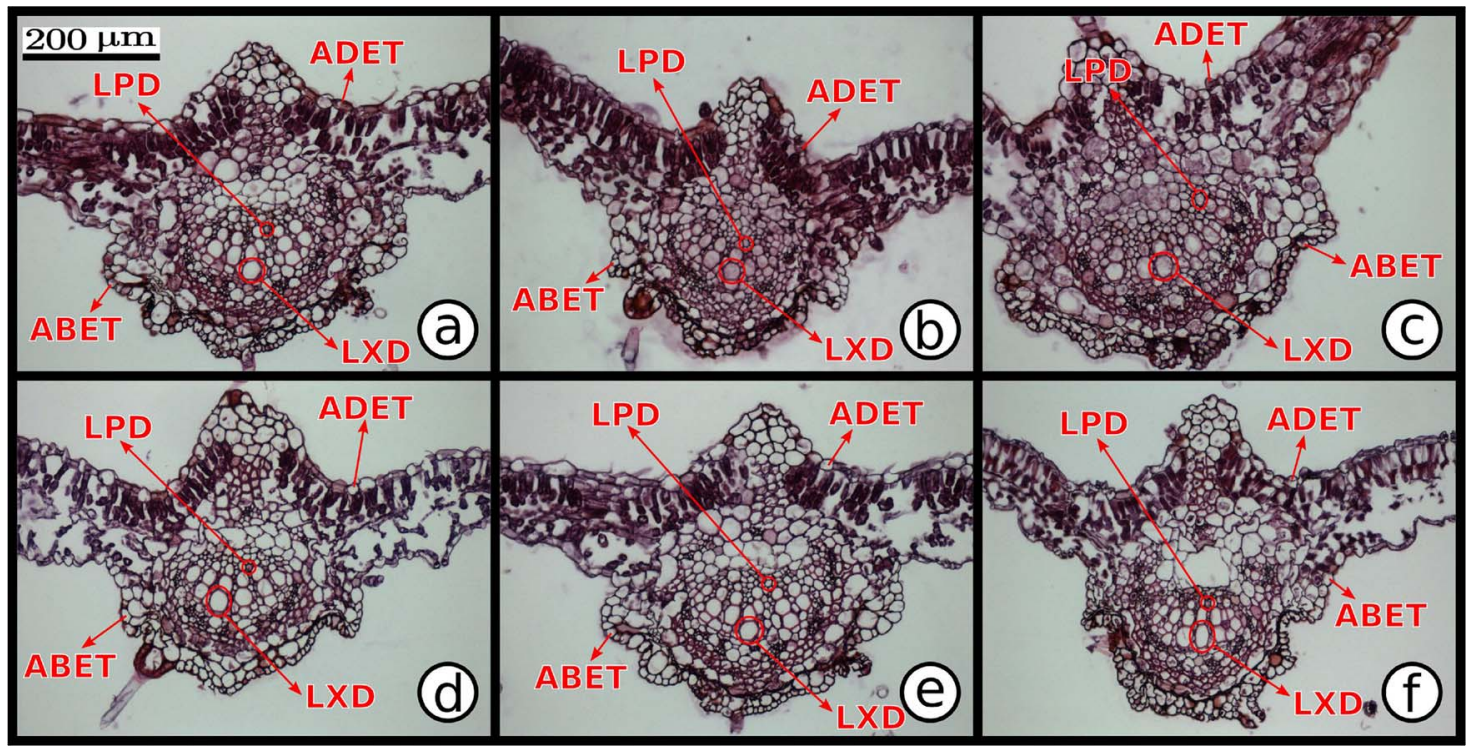

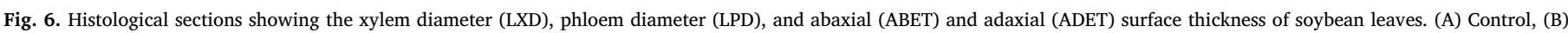
$0.05 \mathrm{mmol} \mathrm{L}^{-1}$, (C) $0.1 \mathrm{mmol} \mathrm{L}^{-1}$, (D) $0.5 \mathrm{mmol} \mathrm{L}^{-1}$, (E) $10 \mathrm{mmol} \mathrm{L}^{-1}$, and (F) $20 \mathrm{mmol} \mathrm{L}^{-1}$. Leaves were harvested after 7 days of exposure to $\mathrm{Ni}$ treatment

present higher nitrate, urea, and protein- and free amino acid-N concentrations, leading to higher activity of $\mathrm{N}$-assimilating enzymes (Kutman et al., 2013, 2014; Alibakhsh and Khoshgoftarmanesh, 2015). However, negative effects on NR activity were observed with increasing $\mathrm{Ni}$ levels. This difference may have been connected to NR degradation by ROS under Ni-toxicity conditions, as previously reported by Shukla et al. (2015). In addition, high Ni supply may decrease the uptake of Mo, which is an NR cofactor (Akpinar et al., 2015). These factors, together with the toxic effect of $\mathrm{Ni}$ on soybean, which affects plant growth and the photosynthetic apparatus (Figs. 1 and 2), negatively affected $\mathrm{N}$ metabolism, significantly affecting NR activity.

Plants exhibiting more evident symptoms of Ni toxicity (grown with $20 \mu \mathrm{mol} \mathrm{L}^{-1} \mathrm{Ni}$; Fig. 8D, E and F) presented higher urease activity (Fig. 3B). Under abiotic-stress conditions (e.g., Ni toxicity), arginine decarboxylase and ornithine decarboxylase activities increase. These enzymes are responsible for arginine degradation, releasing spermidine 

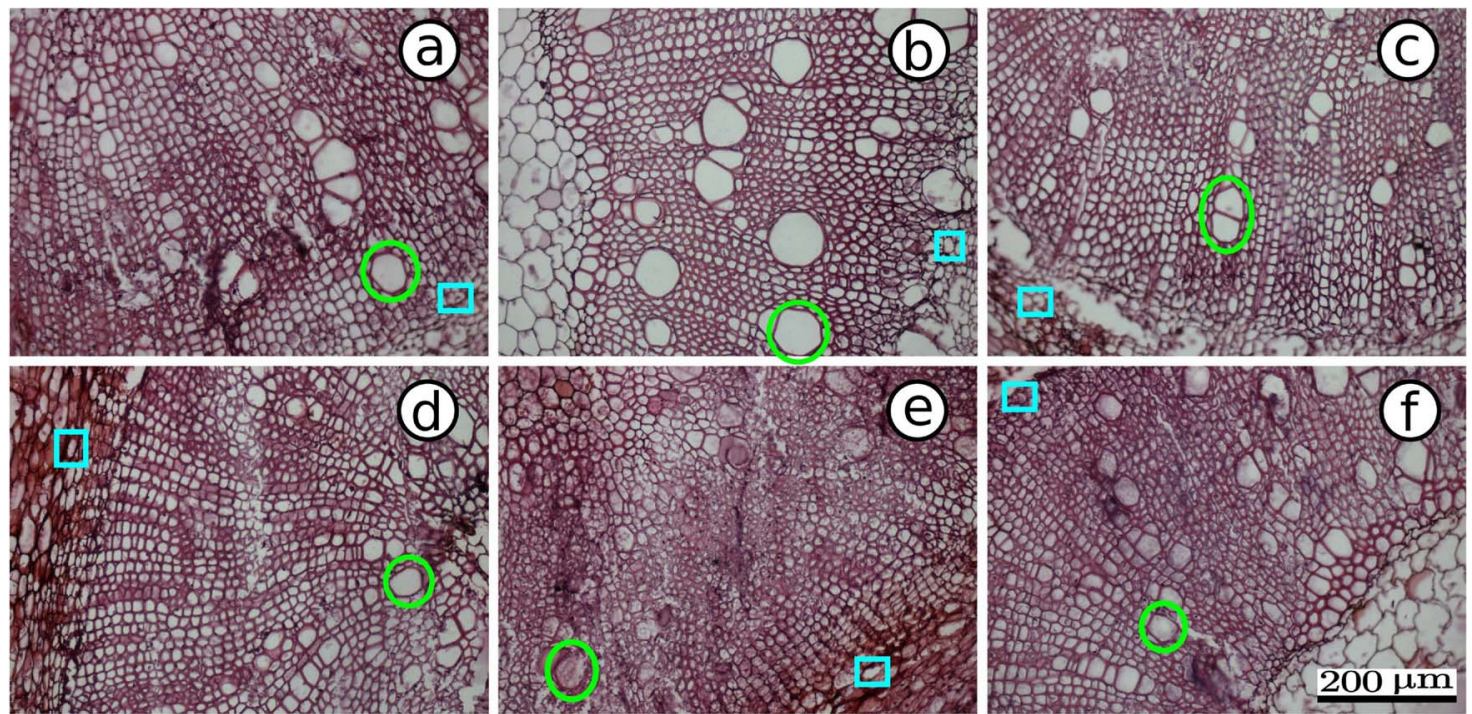

Fig. 7. Histological sections showing the root xylem diameter (green circle) and root phloem diameter (blue square) of soybean plants. (A) Control, (B) $0.05 \mathrm{mmol} \mathrm{L}^{-1}$, (C) $0.1 \mathrm{mmol} \mathrm{L}^{-1}$, (D) $0.5 \mathrm{mmol} \mathrm{L}^{-1}$, (E) $10 \mathrm{mmol} \mathrm{L}^{-1}$, and (F) $20 \mathrm{mmol} \mathrm{L}^{-1}$. The leaves were harvested after 7 days of exposure to Ni treatment. (For interpretation of the references to colour in this figure legend, the reader is referred to the web version of this article.)
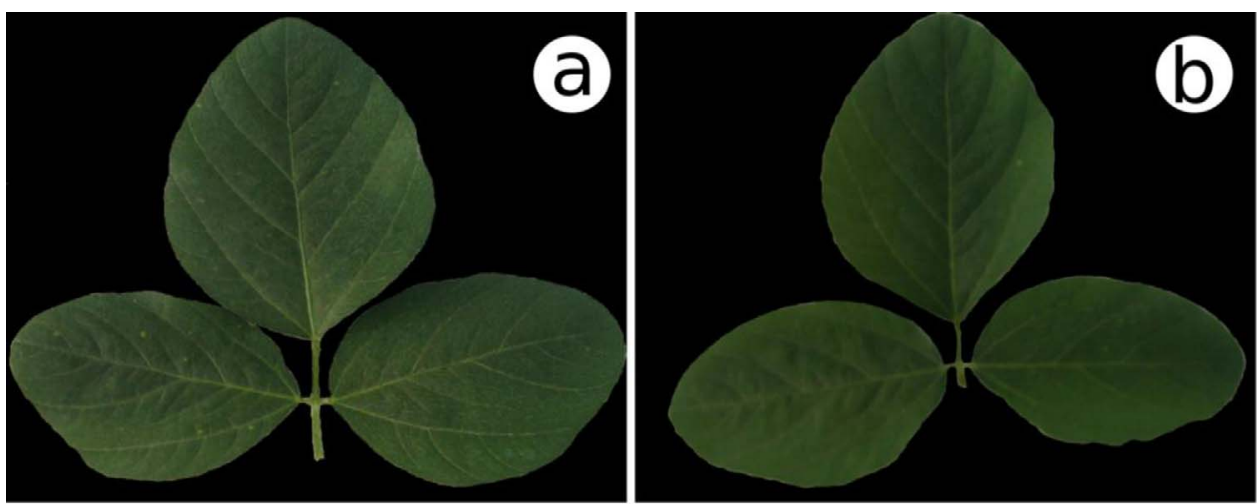

Fig. 8. Soybean leaves showing Ni toxicity symptoms. (A) Control, (B) $0.05 \mathrm{mmol} \mathrm{L}^{-1}, \quad$ (C) $0.1 \mathrm{mmol} \mathrm{L}^{-1}$, (D) $0.5 \mathrm{mmol} \mathrm{L}^{-1}$, (E) $10 \mathrm{mmol} \mathrm{L}^{-1}$, and (F) $20 \mathrm{mmol} \mathrm{L}^{-1}$. Leaves were harvested after 7 days of exposure to Ni treatment.
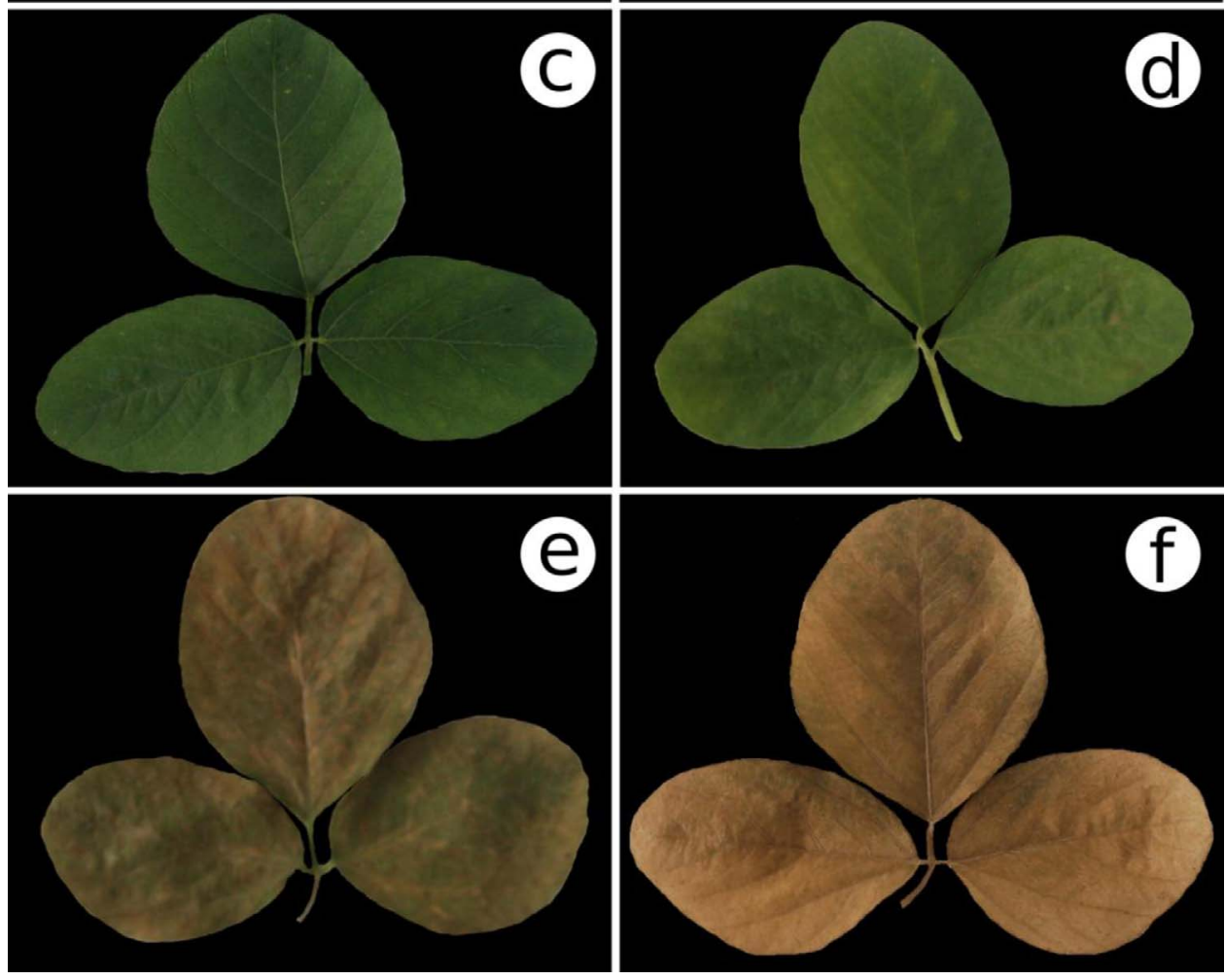

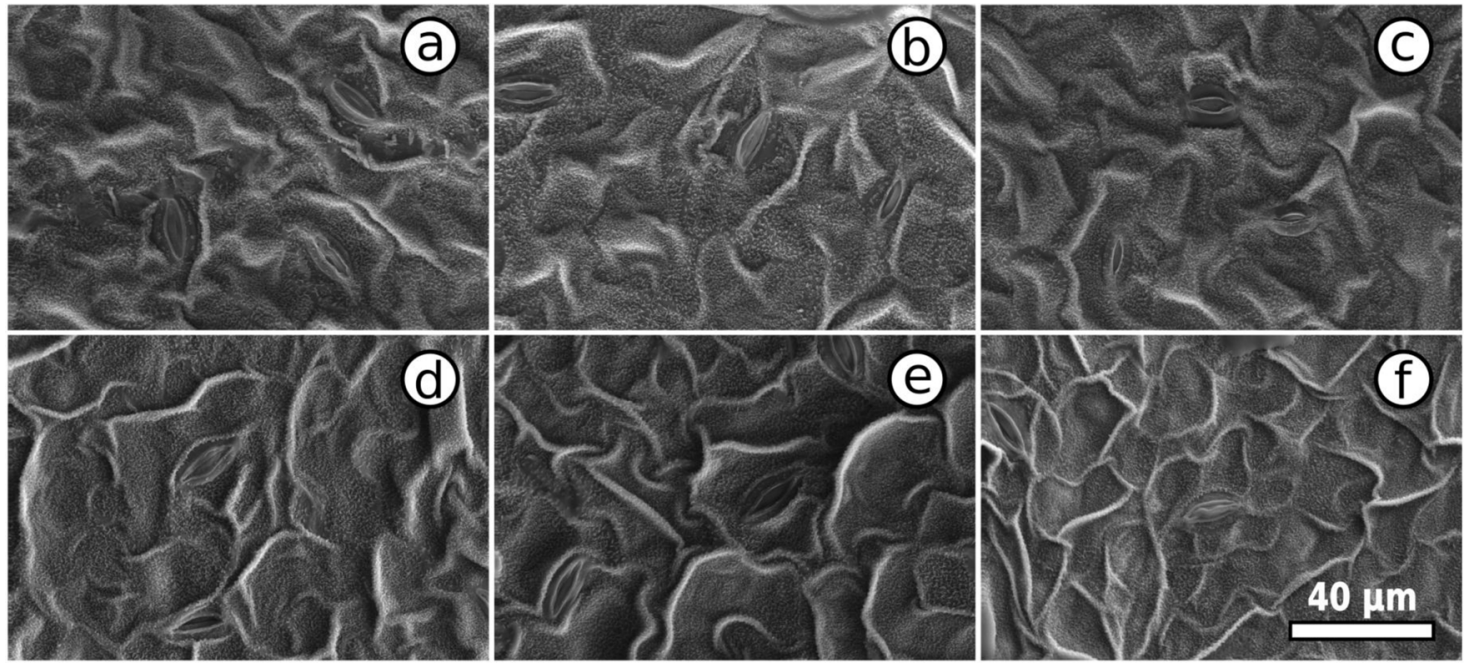

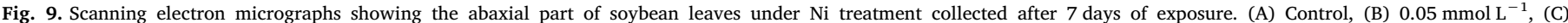
$0.1 \mathrm{mmol} \mathrm{L}^{-1}$, (D) $0.5 \mathrm{mmol} \mathrm{L}^{-1}$, (E) $10 \mathrm{mmol} \mathrm{L}^{-1}$, and (F) $20 \mathrm{mmol} \mathrm{L}^{-1}$. Leaves were harvested after 7 days of exposure to Ni treatment.
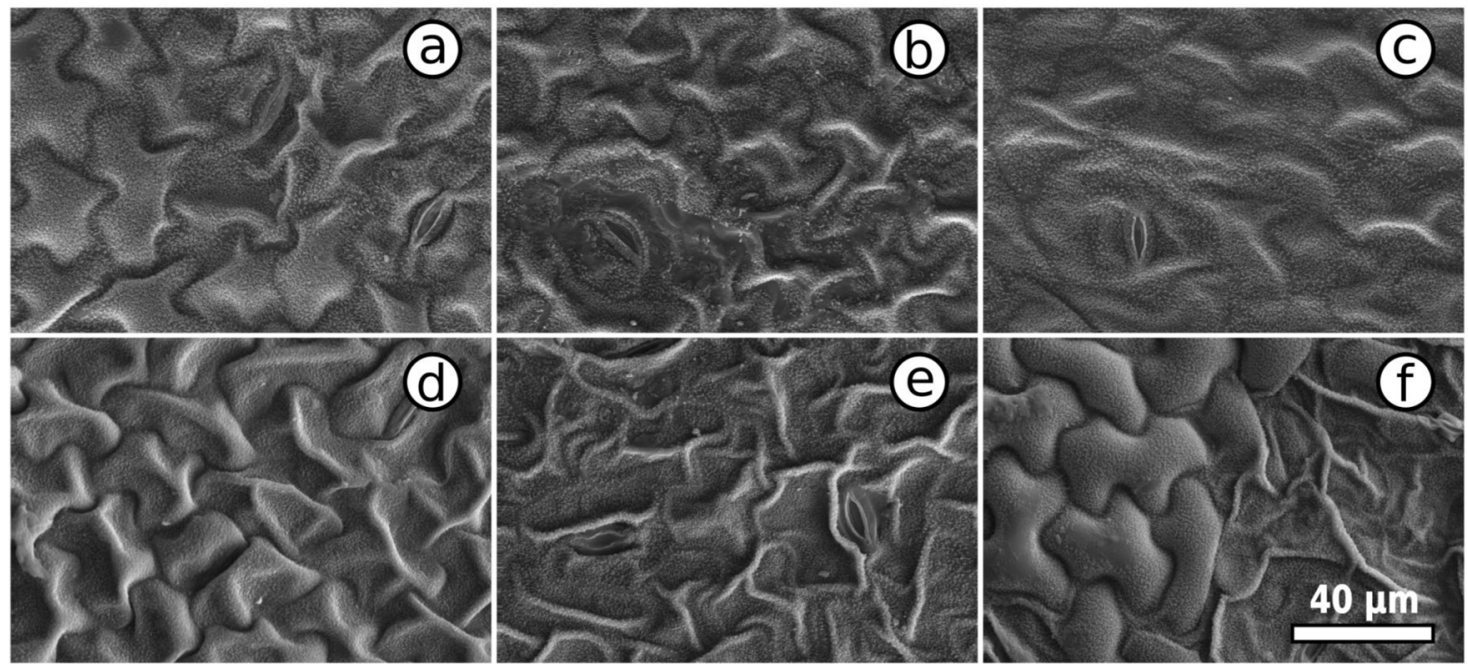

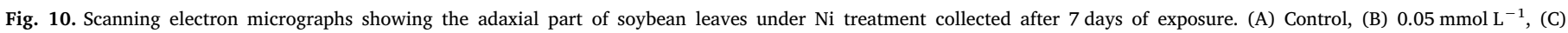
$0.1 \mathrm{mmol} \mathrm{L}^{-1}$, (D) $0.5 \mathrm{mmol} \mathrm{L}^{-1}$, (E) $10 \mathrm{mmol} \mathrm{L}^{-1}$, and (F) $20 \mathrm{mmol} \mathrm{L}^{-1}$. Leaves were harvested after 7 days of exposure to Ni treatment.

and spermine inside mitochondria and urea into the cytosol (Talaat and Shawky, 2016). Urea release into the cytosol increases urease activity (Polacco et al., 2013), similar to that observed in the present study (Fig. 3B). Thus, the observed increase in urease activity was likely a response to arginine degradation and the consequent increase in the cytosolic urea concentration. In addition, the higher Ni uptake in plants grown in $20 \mu \mathrm{mol} \mathrm{L}^{-1} \mathrm{Ni}$ (Fig. 12) also stimulated urease activity. A correlation between leaf $\mathrm{Ni}$ concentrations and urease activity has been previously reported for soybean (Macedo et al., 2016).

The decrease in $A$, Gs and $E$ and increase in $C_{I}$ (Fig. 2) indicated a toxic effect on the photosynthetic apparatus of soybean plants. Metal toxicity increases the concentration of ROS, which decrease the quantum yield and Hill reaction activity and degrade chlorophyll (Pietrini et al., 2015; Shukla et al., 2015; Sirhindi et al., 2016). The lower $A$ combined with higher $C_{I}$ - partly due to lower $G s$, i.e., closed stomata - indicate that Ni toxicity, in addition to the common metal toxic effects on photosynthesis, also decreases the C fixation capacity of soybean plants. The observed changes in the organization and conformation of root xylem and phloem (Fig. 5C and D) also resulted in lower $E$. Changes to the root vessels lead to decreased turgor in shoot tissues, cause stomatal closure on the adaxial and abaxial leaf surface, and promote disorganization of leaf tissues (Pietrini et al., 2015;
Armendariz et al., 2016), as observed in the present study (Figs. 5A, B and 6).

\subsection{Antioxidant enzymes}

Decreasing plant soluble protein concentrations may have a direct effect on Ni toxicity. High Ni concentrations in leaf tissues (Fig. 12) induce the accumulation of $\mathrm{Ni}$ in the cationic form $\left(\mathrm{Ni}^{2+}\right)$, which can change the chromatin protein profile and result in genotoxic effects, resulting in decreased soluble protein content (Erturk et al., 2016). In addition, $\mathrm{Ni}^{2+}$ can also affect cytokinin methylation, causing DNA hypo- or hypermethylation. Under conditions of hypomethylation, chromosomes are more susceptible to breaks, whereas hypermethylation causes chromosome instability, with detrimental effects to cells (Kovalchuk et al., 2001), decreasing protein synthesis and increasing free amino acid content (El Shintinawy and El Ansary, 2000).

CAT activity increased only at $0.5 \mu \mathrm{mol} \mathrm{L}^{-1} \mathrm{Ni}$ (Fig. 4G and $\mathrm{H}$ ), whereas the same was not observed for SOD and POD (Fig. 4). SOD and POD activity increased with increasing Ni concentrations in the nutrient solution. The decrease in CAT activity can be attributed to excess production of ROS, which have their ligand in an inactivated heme group (Willekens et al., 1997). Cakmak and Horst (1991) suggested that 

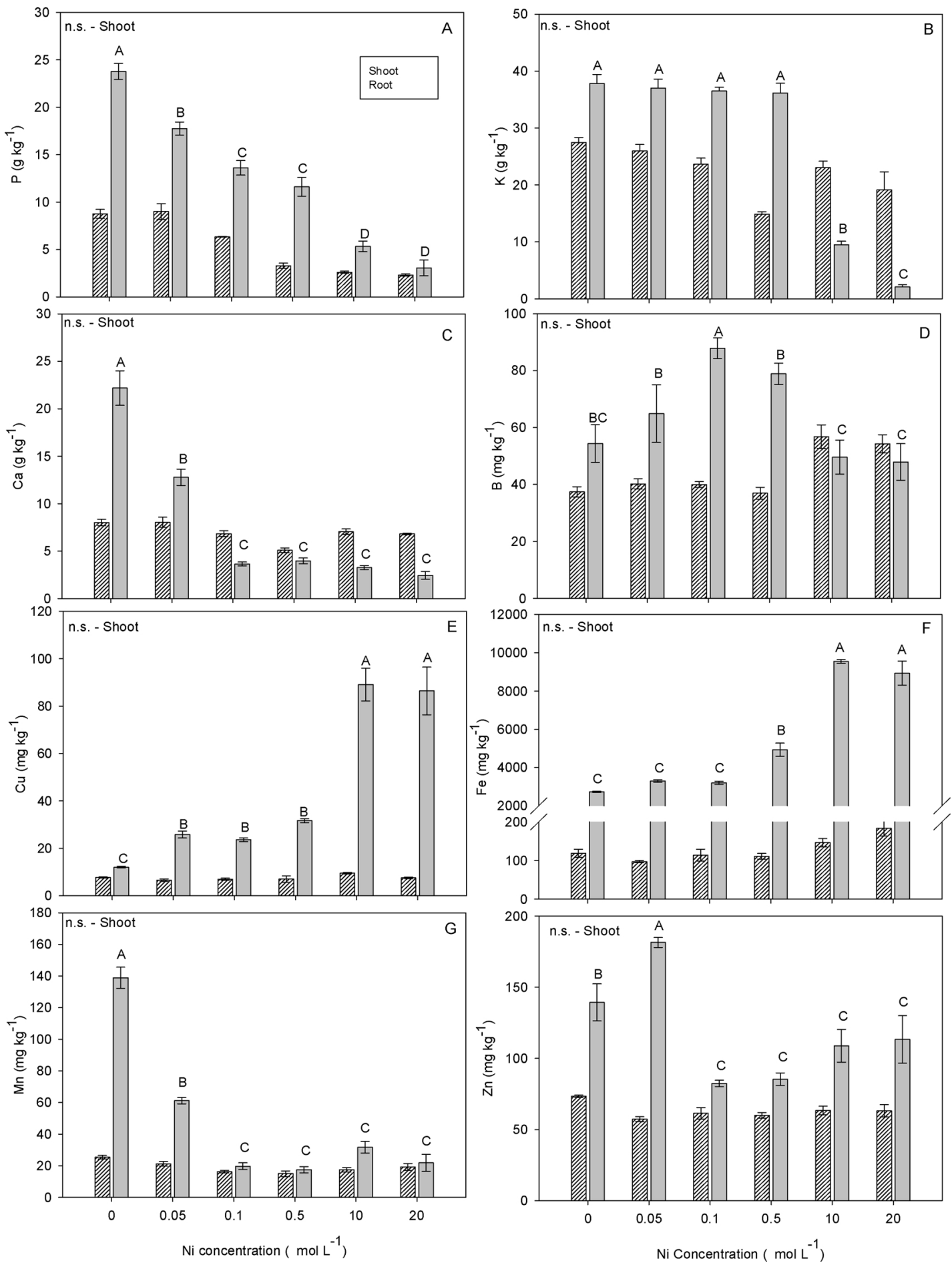

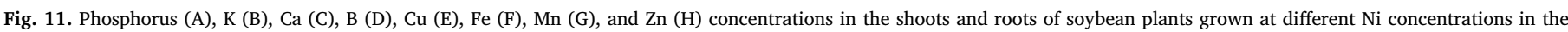

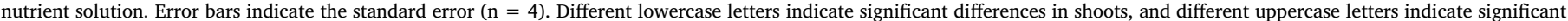
differences in roots, according to the Tukey test $(P<0.05)$. ns: non-significant.

decreased CAT activity and increased POD activity in plants under stress conditions indicate that the generated $\mathrm{H}_{2} \mathrm{O}_{2}$ is mostly consumed by oxidative processes, such as lipid peroxidation.

SOD and POD activity in roots increased significantly at toxic Ni levels (Fig. 4D and F), similar to observations by Gajewska and Skłodowska (2005). Ni uptake by roots causes increased NADPH oxidase activity, peaking only $12 \mathrm{~h}$ after Ni supplementation (Hao et al., 2006). In addition, excess $\mathrm{Ni}$ results in increased $\mathrm{O}_{2}{ }^{-}$and $\mathrm{H}_{2} \mathrm{O}_{2}$ concentrations, the latter originating from $\mathrm{O}_{2}{ }^{-}$dismutation by SOD (Hao et al., 2006).

The increase in antioxidant enzyme activity at increasing $\mathrm{Ni}$ concentrations in the nutrient solution was less pronounced in shoots than in roots, probably due to decreased long-distance transportation and $\mathrm{Ni}$ accumulation in shoots at the time of evaluation. In wheat, after a 48-h exposure to $\mathrm{Ni}$ in the nutrient solution, only $35 \%$ of the total Ni taken by plants was translocated to the shoots (Dalir and Khoshgoftarmanesh, 2014). However, the increasing Ni supplies were sufficient to induce an increase in root antioxidant enzyme activity of up to fourfold relative to 


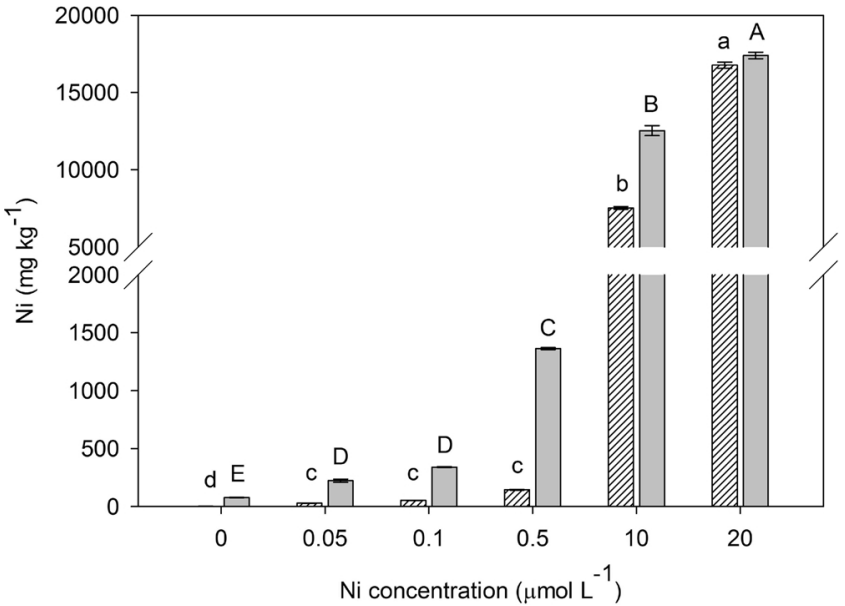

Fig. 12. Ni concentrations in the shoots and roots of soybean plants grown at different $\mathrm{Ni}$ concentrations in the nutrient solution. Error bars indicate the standard error $(n=4)$. Different lowercase letters indicate significant differences in shoots, and different uppercase letters indicate significant differences in roots, according to the Tukey test $(\mathrm{P}<0.05)$. ns: non-significant.

control plants (Fig. 4C, D and G).

CAT activity presented very similar behavior in roots and shoots (Fig. 4G and $\mathrm{H}$ ) but differed slightly from the behavior of the remaining oxidative stress enzymes. This difference was due to the proteolytic degradation of CAT in peroxisomes when leaves undergo senescence (Distefano et al., 1999), leading to CAT inactivation with increasing heavy-metal stress. Decreased CAT activity was reported to be compensated by increased POD activity in Brassica napus (Nouairi et al., 2009), which was also observed in the present study.

\subsection{Ni toxicity symptoms and leaf and root ultrastructural changes}

The detrimental effect of high Ni supplies on plant metabolism directly affected sap and photoassimilate transport by reducing the root phloem and xylem diameter (Fig. 5C and D), showing that Ni supplies above $0.05 \mu \mathrm{mol} \mathrm{L}^{-1}$ had a negative effect on leaf tissue development (Figs. 6 and 8).

The observed brown color on soybean leaves (Fig. 8C and D) was induced by the presence of $\mathrm{Ni}$ inside leaf cells. High leaf $\mathrm{Ni}$ concentrations induced the production of plastoglobules, which act as a plant defense mechanism (Pookothai and Vijayavathi, 2012). Increases in the number and size of plastoglobules in chloroplasts negatively affect the synthesis of lipid bodies, which help protect the photosynthetic apparatus against free radicals (Moraes et al., 2014). These Ni toxicity symptoms were also observed in the leaves of cabbage (Molas, 1997), wheat (Seregin and Kozhevnikova, 2006), and cauliflower (Shukla et al., 2015). These authors also observed decreased mesophyll thickness and epidermal cell width, as well as smaller vascular bundles. It should be noted that the decrease in leaf epidermal thickness observed in the present study directly affects resistance to mechanical, chemical and biological damage. This finding is in agreement with Seregin and Kozhevnikova (2006), who reported detrimental effects of $\mathrm{Ni}$ on internal leaf morphology.

\subsection{Macro- and micronutrient concentrations}

Ni uptake is a multiphasic process (more than one isotherm is needed to describe uptake velocity), and $\mathrm{Ni}$ is transported via the xylem as complexes or organic anion chelates. Under toxicity conditions, $\mathrm{Ni}$ uptake is compromised, and high leaf $\mathrm{Ni}$ concentrations antagonize similar ions. In the present study, P, K, Ca, Mn, and Zn uptake was observed to decrease (Fig. 11). This decrease was mainly due to the toxic effect of $\mathrm{Ni}$ on plant growth. The uptake of these nutrients was therefore compromised in plants grown in the highest Ni levels, resulting in lower $\mathrm{P}, \mathrm{K}, \mathrm{Ca}, \mathrm{Mn}$ and $\mathrm{Zn}$ concentrations in roots. However, root $\mathrm{Cu}$ and $\mathrm{Fe}$ concentration was observed to increase.

The interaction between $\mathrm{Ni}$ and $\mathrm{Cu}$ is antagonistic, and competition between them has been observed in soybean (Cataldo et al., 1978) and barley (Korner et al., 1987). On the other hand, Ni toxicity in the field is often associated with $\mathrm{Cu}$ toxicity, indicating a synergy between the two, although this effect is not well understood (Küpper and Andresen, 2016). The same can be said about the interaction between $\mathrm{Ni}$ and $\mathrm{Fe}$ since the presence of $\mathrm{Ni}$ has been reported to decrease Fe uptake. Nishida et al. (2015) studied Ni uptake by Fe transporters and observed that Ni not only uses Fe transporters but also induces plants to produce more Fe transporters, which may have resulted in higher Fe uptake by roots. In the present study, exudation of organic acids by roots may have favored $\mathrm{Ni}$ and Fe uptake by roots.

\section{Conclusions}

Soybean plants exhibited symptoms of $\mathrm{Ni}$ toxicity starting at $0.1 \mu \mathrm{mol} \mathrm{L}^{-1} \mathrm{Ni}$, corresponding to a shoot $\mathrm{Ni}$ concentration of $28.9 \mathrm{mg} \mathrm{kg}^{-1}$, presenting decreased carbon dioxide assimilation and shoot and root dry mass.

The activity of antioxidant enzymes - CAT, POD and SOD - increased in roots and shoots with increasing Ni uptake. Root xylem and phloem diameter, as well as leaf adaxial and abaxial epidermal thickness, decreased starting at $0.1 \mu \mathrm{mol} \mathrm{L}{ }^{-1} \mathrm{Ni}$. These results contribute to our understanding of several basic mechanisms of Ni toxicity in soybean, which remains poorly understood.

\section{Acknowledgements}

This work was financially supported by a grant from the National Council for Scientific and Technological Development (Grant 448783/ 2014-2). The authors would like to thank the CAPES Foundation for studentship (JPQB) and (JMKS) granted.

\section{References}

Ahmad, M.S.A., Hussain, M., Saddiq, R., Alvi, A.K., 2007. Mung bean: a nickel indicator: accumulator or excluder. Bull. Environ. Contam. Toxicol. 78, 319-324.

Ahmad, P., Sarwat, M., Bhat, N.A., Wani, M.R., Kazi, A.G., Tran, L.S.P., 2015. Alleviation of cadmium toxicity in Brassica juncea L. (Czern. \& Coss.) by calcium application involves various physiological and biochemical strategies. PLoS One 10, e0114571.

Ahmad, P., 2013. Oxidative Damage to Plants, Antioxidant Networks and Signaling. Academic Press, Cambridge, MA.

Akpinar, A., Arslan, H., Güleryüz, G., Kırmızı, S., Erdemİr, Ü.S., Güçer, Ş., 2015. Ni-induced changes in nitrate assimilation and antioxidant metabolism of verbascum olympicum boiss.: could the plant be useful for phytoremediation or/and restoration purposes? Int. J. Phytorem. 17, 546-555.

Alibakhsh, M., Khoshgoftarmanesh, A.H., 2015. Effects of nickel nutrition in the mineral form and complexed with histidine in the nitrogen metabolism of onion bulb. Plant Growth Regul. 75, 733-740.

Allain, C.C., Poon, L.S., Chan, C.S.G., Richmond, W., Fu, P.C., 1974. Enzymatic determination of total serum cholesterol. Clin. Chem. 120, 470-475.

Armendariz, A.L., Talano, M.A., Villasuso, A.L., Travaglia, C., Racagni, G.E., Reinoso, H., Agostini, E., 2016. Arsenic stress induces changes in lipid signalling and evokes the stomata closure in soybean. Plant Physiol. Biochem. 103, 45-52.

Azevedo, R.A., Alas, R.M., Smith, R.J., Lea, P.J., 1998. Response of antioxidant enzymes to transfer from elevated carbon dioxide to air and ozone fumigation, in the leaves and roots of wild-type and a catalase-deficient mutant of barley. Physiol. Plant. 104, $280-292$.

Bishnoi, N.R., Sheoran, I.S., Singh, R., 1993. Influence of cadmium and nickel on photosynthesis and water relations in wheat leaves of different insertion level. Photosynthetica 28, 473-479.

Bradford, M.M., 1976. A rapid and sensitive method for the quantitation of microgram quantities of protein utilizing principle of protein-dye-binding. Anal. Biochem. 72, 248-254.

Cakmak, I., Horst, W.J., 1991. Effect of aluminium on lipid peroxidation, superoxide dismutase, catalase, and peroxidase activities in root tips of soybean (Glycine max). Physiol. Plant. 83, 463-468.

Carlquist, S.J., 1975. Ecological strategies of xylem evolution. University of California Press, Berkley CA.

Cataldo, D.A., Garland, T.R., Wildung, R.E., 1978. Nickel in plants. I: Uptake kinetics using intact soybean seedlings. Plant Physiol. 62, 5636-5665. 
Dalir, N., Khoshgoftarmanesh, A.H., 2014. Symplastic and apoplastic uptake and root to shoot translocation of nickel in wheat as affected by exogenous amino acids. J. Plant Physiol. 171, 531-536.

Distefano, S., Palma, J.M., McCarthy, I., del Rio, L.A., 1999. Proteolytic cleavage of plant proteins by peroxisomal endoproteases from senescent pea leaves. Planta 209 (3), 308-313.

Dixon, N.E., Gazzola, C., Brakeley, R.L., Zerne, B., 1975. Jack-bean urease (EC 3.5.1.5.3). metalloenzyme. a simple biological role for nickel. J. Am. Chem. Soc. 97 (14), 4131-4133.

Drazkiewicz, M., Baszynki, T., 2010. Interference of nickel with the photosynthetic apparatus of Zea mays. Ecotoxicol. Environ. Saf. 73, 982-986.

El Shintinawy, F., El Ansary, A., 2000. Differential effect of $\mathrm{Cd} 2+$ and $\mathrm{Ni} 2+$ on amino acid metabolism in soybean seedlings. Biol. Plant. 43 (1), 79-84.

Erturk, F.A., Ay, H., Nardemir, G., 2016. Molecular determination of genotoxic effects of cobalt and nickel on maize (Zea mays L.) by RAPD and protein analyses. Toxicol. Ind. Health 29, 662-671.

Fabiano, C.C., Tezotto, T., Favarin, J.L., Polacco, J.C., Mazzafera, P., 2015. Essentiality of nickel in plants: a role in plant stresses. Front. Plant Sci. 6, 754. http://dx.doi.org/10. 3389/fpls.2015.00754.

Gajewska, E., Skłodowska, M., 2005. Antioxidative responses and proline level in leaves and roots of pea plants subjected to nickel stress. Acta Physiol. Plant. 27 (3), 329-340.

Gajewska, E., Sklodowska, M., Slaba, M., Mazur, J., 2006. Effect of nickel on antioxidative enzyme activities: proline and chlorophyll contents in wheat shoots. Biol. Plant. 50, 653-659.

Giannopolitis, C.N., Ries, S.K., 1977. Superoxide dismutases: I. Occurrence in higher plants. Plant Physiol. 59 (2), 309-314.

Granick, S., 1951. Biosynthesis of chlorophyll and related pigments. Annu. Rev. Plant Physiol. 2, 115-144.

Gustafsson, J.P., 2011. Visual MINTEQ Ver. 3.0. KTH. Department of Land and Water Resources Engineering. http://www2.lwr.kth.se/English/OurSoftware/vminteq/.

Hao, F., Wang, X., Chen, J., 2006. Involvement of plasma-membrane NADPH oxidase in nickel-induced oxidative stress in roots of wheat seedlings. Plant Sci. 170 (1), 151-158.

Hewitt, E.J., 1953. Metal interrelationship in plant nutrition. J. Exp. Bot. 4 (1), 59-64. Hoagland, D.R., Arnon, D.I., 1950. The Water-Culture Method for Growing Plants Without Soil. California Agricultural Experiment Station Circular 347. College of Agriculture, University of California, Berkeley.

Hogan, M.E., Swift, I.E., Done, J., 1983. Urease assay and ammonia release from leaf tissues. Phytochemistry 22, 663-667.

Küpper, H., Andresen, E., 2016. Mechanisms of metal toxicity in plants. Metallomics 8, $269-285$

Küpper, H., Kroneck, P.M.H., 2007. Nickel in the environment and its role in the metabolism of plants and cyanobacteria. In: In: Sigel, A., Sigel, H., Sigel, R.K.O. (Eds.), Nickel and Its Surprising Impact in Nature, vol. 2 Wiley J. Ltd., West Sussex (ch. 5, pp. 31).

Kabata-Pendias, A., Pendias, H., 2011. Trace Elements in Soil and Plants, vol. 4 CRC Press (548 p).

Kazemi, N., Khavari-Nejad, R.A., Fahimi, H., Saadatmand, S., Nejad-Sattari, T., 2010. Effects of exogenous salicylic acid and nitric oxide on lipid peroxidation and antioxidant enzyme activities in leaves of Brassica napus L. under nickel stress. Sci. Hortic.-Amsterdam 126 (3), 402-407.

Korner, L.E., Moller, L., Jensén, M.P., 1987. Effects of Ca2 + and other divalent cations on uptake of Ni2 + by excised barley roots. Physiol. Plant. 71, 49-54.

Kovalchuk, O., Titov, V., Hohn, B., Kovalchuk, I., 2001. A sensitive transgenic plant system to detect toxic inorganic compounds in the environment. Nat. Biotechnol. 19, 568-572.

Kutman, B.Y., Kutman, U.B., Cakmak, I., 2013. Nickel-enriched seed and externally supplied nickel improve growth and alleviate foliar urea damage in soybean. Plant Soil 363, 61-75.

Kutman, B.Y., Kutman, U.B., Cakmak, I., 2014. Effects of seed nickel reserves or externally supplied nickel on the growth, nitrogen metabolites and nitrogen use efficiency of urea- or nitrate-fed soybean. Plant Soil 376, 261-276.

Lavres Junior, J., Malavolta, E., Nogueira, N.L., Moraes, M.F., Reis, A.R., Rossi, M.L., Cabral, C.P., 2009. Changes in anatomy and root cell ultrastructure of soybean genotypes under manganese stress. R. Bras. Ciê. Solo 33, 395-403.

Lavres Junior, J., Reis, A.R., Rossi, M.L., Cabral, C.P., Nogueira, N.L., Malavolta, E., 2010. Changes in the ultrastructure of three soybean cultivars in response to manganese supply in solution culture. Sci. Agric. 67, 287-294.

Lavres, J., Castro, F.G., de Sousa Câmara, G.M., 2016. Soybean seed treatment with nickel improves biological fixation and urease activity. Front. Environ. Sci. 4, 1-11.

Macedo, F.G., Bresolin, J.D., Santos, E.F., Furlan, F., Silva, W.T., Polacco, J.C., Lavres, J., 2016. Nickel availability in soil as influenced by liming and its role in soybean nitrogen metabolism. Front. Plant Sci. 7, 1358. http://dx.doi.org/10.3389/fpls.2016. 01358.

McCullough, H., 1967. The determination of ammonia in whole blood by a direct colorimetric method. Clín. Chim. Acta 17, 297-304.

Miller, R.O., 1998. Nitric-perchloric acid wet digestion in an open vessel. In: Karla, Y.P.
(Ed.), Handbook of Reference Methods for Plant Analysis. CRC Press, Boca Raton, FL (pp. 57e61).

Mishra, D., Kar, M., 1974. Nickel in plant growth and metabolism. Bot. Rev. 40, 395-452.

Mohanty, N., Vaas, I., Demeter, S., 1989. Impairment of photosystem 2 activity at the level of secondary quinone electron acceptor in chloroplasts treated with cobalt nickel and zinc ions. Physiol. Plant. 76, 386-390.

Molas, J., 1997. Changes in morphological and anatomical structure of cabbage (Brassica oleracea L.) outer leaves and in ultrastructure of their chloroplasts caused by an in vitro excess of nickel. Photosynthetica 34, 513-522.

Moraes, C.L., Marini, P., Fernando, J.A., Moraes, D.M., Castro, L.A.S., Lopes, N.F., 2014 Physiological and ultra-structural changes in tomato seedlings induced by lead. Iheringia Serie Bot. 69, 313-322 (In Portuguese).

Nishida, S., Kato, A., Tsuzuki, C., Yoshida, J., Mizuno, T., 2015. Induction of nickel accumulation in response to zinc deficiency in Arabidopsis thaliana. Intern. J. Mol. Sci. $16,9420-9430$.

Nolan, A.L., Ma, Y., Lombi, E., McLaughlin, M.J., 2009. Speciation and isotopic exchangeability of nickel in soil solution. J. Environ. Qual. 38 (2), 485-492.

Nouairi, I., Ben Ammar, W., Ben Youssef, N., Ben Miled, D.D., Ghorbal, M.H., Zarrouk, M., 2009. Antioxidant defense system in leaves of Indian mustard (Brassica juncea) and rape (Brassica napus) under cadmium stress. Acta Physiol. Plant. 31, 237-247.

Pandolfini, T., Gabbrielli, R., Comparini, C., 1992. Nickel toxicity and peroxidase activity in seedlings of Triticum aestivum L. Plant. Cell Environ. 15, 719-725.

Pietrini, F., Iori, V., Cheremisina, A., Shevyakova, N.I., Radyukina, N., Kuznetsov, V.V., Zacchini, M., 2015. Evaluation of nickel tolerance in Amaranthus paniculatus L. plants by measuring photosynthesis oxidative status, antioxidative response and metal-binding molecule content. Environ. Sci. Pollut. Res. Int. 22, 482-494.

Polacco, J.C., Mazzafera, P., Tezotto, T., 2013. Opinion-Nickel and urease in plants: still many knowledge gaps. Plant Sci. 199, 79-90.

Pookothai, M., Vijayavathi, B.S., 2012. Nickel as an essential element and a toxicant. Intern. J. Environ. Sci. 1, 285-288.

Reis, A.R., Favarin, J.L., Gallo, L.A., Malavolta, E., Moraes, M.F., Lavres Junior, J., 2009. Nitrate reductase and glutamine synthetase activity in coffee leaves during fruit development. Rev. Bras. Ciê. Solo 33, 315-324.

Reis, A.R., Favarin, J.L., Gratão, P.L., Capaldi, F.R., Azevedo, R.A., 2015. Antioxidant metabolism in coffee (Coffea arabica L.) plants in response to nitrogen supply. Theor. Exp. Plant Physiol. 1, 1-11.

Ruter, J.M., 2005. Effect of nickel applications for the control of mouse ear disorder on river birch. J. Environ. Hort. 23, 17-20.

Santos, E.F., Santini, J.M.K., Paixão, A.P., Furlani Júnior, E., Lavres, J., Campos, M., Reis, A.R., 2017. Physiological highlights of manganese toxicity symptoms in soybean plants: mn toxicity responses. Plant Physiol. Biochem. 113, 6-19.

Schickler, H., Caspi, H., 1999. Response of antioxidative enzymes to nickel and cadmium stress in hyperaccumulator plants of the genus Alyssum. Physiol. Plant. 105, 39-44.

Seregin, I.V., Ivanov, V.B., 2001. Physiological aspects of cadmium and lead toxic effects on higher plants. Russ. J. Plant Physiol. 48 (4), 523-544.

Seregin, I.V., Kozhevnikova, A.D., 2006. Physiological role of nickel and its toxic effects on higher plants. Russ. J. Plant Physiol. 53, 257-277.

Sheoran, I.S., Singal, H.R., Singh, R., 1990. Effect of cadmium and nickel on photosynthesis and the enzymes of the photosynthetic carbon reduction cycle in pigeonpea (Cajanus cajan L.). Photosynth. Res. 23, 345-351.

Shukla, R., Sharma, Y.K., Gopal, R., 2015. Evaluation of toxicity level of nickel on growth photosynthetic efficiency, antioxidative enzyme, and its accumulation in cauliflower. Commun. Soil Sci. Plant Anal. 46, 2866-2876.

Sirhindi, G., Mir, M.A., Abd-Allah, E.F., Ahmad, P., Gucel, S., 2016. Jasmonic acid modulates the physio-biochemical attributes, antioxidant enzyme activity, and gene expression in Glycine max under nickel toxicity. Front. Plant Sci. 7, 1-12.

Sreekanth, T., Nagajyothi, P., Lee, K., Prasad, T., 2013. Occurrence: physiological responses and toxicity of nickel in plants. Int. J. Environ. Sci. Technol. 10, 1129-1140.

Talaat, N.B., Shawky, B.T., 2016. Dual application of 24-epibrassinolide and spermine confers drought stress tolerance in maize (Zea mays L.) by modulating polyamine and protein metabolism. J. Plant Growth Regul. 35, 518-533.

Tripathy, B.C., Bhatia, B., Mohanty, P., 1983. Cobalt ions inhibit electron transport activity of photosystem II without affecting photosystem I. Biochem. Biophys. Acta 722, 88-93.

Uren, N.C., 1992. Forms reactions, and availability of nickel in soils. Adv. Agron. 48, 141-203.

Velikova, V., Tsonev, T., Loreto, F., Centritto, M., 2011. Changes in photosynthesis mesophyll conductance to $\mathrm{CO} 2$, and isoprenoid emissions in Populus nigra plants exposed to excess nickel. Environ. Pollut. 159, 1058-1066.

White, P.J., 2012. Long-distance transport in the xylem and phloem. In: Marscher, P. (Ed.), Marschner's Mineral Nutrition of Higher Plants, 3rd ed. Academic Press, London, pp. 49-70.

Willekens, H., Chamnongpol, S., Davey, M., Schaudner, M., Langebartels, C., Van Montagu, M., Inzé, D., Van Camp, W., 1997. Catalase is a sink for H2O2 and is indispensable for stress defence in C3 plants. EMBO J. 16, 4806-4816.

Wood, B.W., Reilly, C.C., Nyczepir, A.P., 2006. Field deficiency of nickel in trees: symptoms and causes. Acta Hortic. 721, 83-97. 